\title{
Chapter 12 \\ The Amphibians of Angola: Early Studies and the Current State of Knowledge
}

\author{
Ninda Baptista, Werner Conradie, Pedro Vaz Pinto, and William R. Branch
}

\begin{abstract}
Angolan amphibians have been studied since the mid-nineteenth century by explorers and scientists from all over the western world, and collections have been deposited in around 20 museums and institutions in Europe, Northern America, and Africa. A significant interruption of this study occurred during Angola's liberation struggle and civil war for nearly four decades and, as a consequence, knowledge about the country's biodiversity became outdated with critical gaps. Since 2009, a new era in Angolan biodiversity studies started as expeditions scattered in southwest-
\end{abstract}

\footnotetext{
N. Baptista $(\bowtie)$

Instituto Superior de Ciências da Educação da Huíla, Rua Sarmento Rodrigues, Lubango, Angola

National Geographic Okavango Wilderness Project, Wild Bird Trust, Parktown, Gauteng, South Africa

CIBIO-InBIO, Centro de Investigação em Biodiversidade e Recursos Genéticos, Laboratório Associado, Universidade do Porto, Vairão, Portugal e-mail: nindabaptista@gmail.com
}

W. Conradie

National Geographic Okavango Wilderness Project, Wild Bird Trust, Hogsback, South Africa School of Natural Resource Management, Nelson Mandela University, George, South Africa

Port Elizabeth Museum (Bayworld), Humewood, South Africa

e-mail: werner@bayworld.co.za

P. Vaz Pinto

Fundação Kissama, Luanda, Angola

CIBIO-InBIO, Centro de Investigação em Biodiversidade e Recursos Genéticos, Universidade do Porto, Campus de Vairão, Vairão, Portugal

e-mail: pedrovazpinto@gmail.com

W. R. Branch (deceased)

National Geographic Okavango Wilderness Project, Wild Bird Trust,

Parktown, Gauteng, South Africa

Department of Zoology, Nelson Mandela University, Port Elizabeth, South Africa 
ern, northeastern, southeastern, and northwestern Angola lead to exciting discoveries, including new records for the country, descriptions of new species, range extensions and taxonomical updates. Currently 111 amphibian species are listed for the country (of which 21 are endemic), but this number is an underestimate and the various unresolved taxonomical issues challenge the study of every other aspect of this group. The Angolan amphibian fauna remains one of the most poorly known in Africa and much still has to be done in order to understand its diversity, evolution and conservation needs. An overview of existing knowledge of Angolan amphibians is presented, including an updated checklist for the country, comments on problematic groups, endemic species, biogeography, recent findings, and priority research topics.

Keywords Angolan escarpment · Checklist · Endemism · Herpetology · Research priorities · Taxonomy

\section{Introduction}

Amphibians are a fascinatingly diverse group that plays crucial ecological roles (Beard et al. 2002; Davic and Welsh 2004; Regester et al. 2006) and are useful as indicators of ecosystem health (Waddle 2006), thus the relevance of their study surpasses herpetological curiosity. Despite the fact that the rate of description of amphibian species in the world is continuously increasing, current taxonomic research is still insufficient to properly inform conservation planning (Köhler et al. 2005; Brito 2010).

Like other groups presented in this book, Angolan amphibians are among the most poorly known in Africa (Conradie et al. 2016). To study this group it is necessary to deal with historical as well as scientific issues including: many species are known from holotypes collected more than a century ago and which may have been subsequently lost; collection localities had old colonial names, some no longer used and others confused with homonyms; a considerable amount of early literature is written in diverse languages (Portuguese, French, German, English and even Latin) and is not easily accessible; and many names used for Angolan taxa have been lost in synonymies and their current status remains problematic. Overviews of the history and evolution of the southern African amphibian taxonomy exist, mentioning Angolan taxa briefly (Poynton 1964; Channing 1999; Du Preez and Carruthers 2009, 2017). This chapter focuses on Angola, and the compiled information is intended to serve as a baseline that facilitates the study of this group. It consists of an essentially chronological summary of the studies of Angolan amphibians since the very first to the most recent findings, presents a checklist of species, and identifies some of the most evident challenges and exciting research priorities. Given the complicated status of many names available for Angolan taxa, species considered as valid in this review follow Frost (2018). An Atlas of historical and bibliographic records of Angolan herpetofauna has been released subsequent to the compilation of information for this chapter (Marques et al. 2018). 


\section{Early Beginnings}

The European exploration and settlement in Africa resulted in the discovery of strange and wondrous animals. As these were sent in increasing numbers to European centres of learning and study, they stimulated the departure of expeditions to explore the Angolan flora and fauna by Portugal and by other nations. The exotic collections obtained by these explorers were then shipped to their home countries, and so, in the nineteenth century, the study of amphibians from Angola started in Europe. This was the case for the rest of southern Africa, the only exception being South Africa, which in the early 1800s already had Andrew Smith, a British explorer and researcher, based in the Cape (Channing 1999; Branch and Bauer 2005).

In 1866, José Vicente Barbosa du Bocage made the first list of amphibians and reptiles from Angola based on assorted specimens deposited in the Natural History Museum of Lisbon (Bocage 1866a, b). It documented only 19 amphibian species, eight of which were new to science and which Bocage (1866b) described (Hyperolius cinnamomeoventris, $H$. tristis, $H$. fuscigula, H. quinquevittatus, H. steindachneri, Rana (=Ptychadena) subpunctata, Rana (=Amietia) angolensis, Bufo funereus (=Sclerophrys funerea). The material came from two expeditions, one by José de Anchieta in 1864 to Cabinda, and the other from Duque de Bragança (now Calandula) by Pinheiro Bayão.

During this period, Europeans were exploring Angola, either on their own initiative, or on behalf of various institutions that promoted scientific expeditions to Angola. Publications from this era consist essentially of descriptions of new species and new distribution records for known species. The renowned Austrian explorer and botanist Friedrich Martin Josef Welwitsch (1806-1872) explored Angola for the Portuguese government, arriving in 1853 and undertaking almost a decade of strenuous exploring and collecting. After his return to Europe his collections were donated to the British Museum, later shared with Portugal, and the Angolan amphibians were reported on by Günther (1865), who described new species of reed frog (Hyperolius nasutus, $H$. parallelus).

Collections from the Austrian frigate Novara were deposited in the Natural History Museum of Vienna and studied by Steindachner (1867), who described Ptychadena porosissima and Hyperolius bocagei from no precise locality. Anchieta persisted in his extensive exploration of Angola, and Bocage (1867, 1873, 1879a, b, $1882,1893,1897 b$ ) examined his specimens, as well as the herpetological collections of Capello \& Ivens (Bocage 1879a, b), describing Hylambates (=Leptopelis) anchietae, Hylambates (=Leptopelis) cynnamomeus, and Rappia (=Hyperolius) benguellensis among other species currently not valid. The German explorers von Homeyer, who collected in Pungo-Andongo, and von Mechow, who collected in Malanje and Cuango, had their specimens deposited in the Zoological Museum of Berlin and studied by Peters (1877, 1882), who described Bufo buchneri from Cabinda. Boulenger (1882) studied the material from the British Museum and described Tomopterna tuberculosa, and Rochebrune (1885) described four new Hyperolius species from Cabinda (H. lucani, $H$. maestus, $H$. protchei, $H$. rhizophilus). 
Bocage (1895a) compiled the extant information about the herpetology of Angola and Congo, using all the above-mentioned references, except for Rochebrune's (1885). A total of 40 species of amphibians were listed for Angola. Even today, more than a century after its release, this work is still a valuable reference on Angolan herpetology. After this, Bocage published several other findings (Bocage 1895b, 1896a, b, 1897a, b), mostly from Anchieta's new collections, with new locality records for many frogs, and the description of a new pygmy toad, Bufo (=Poyntonophrynus) dombensis

From 1898 to 1906, José Júlio Bethencourt Ferreira studied Angolan material collected by Anchieta, Francisco Newton and Pereira do Nascimento (Ferreira 1897, 1900, 1904, 1906), and described new species (Rappia (=Afrixalus) osorioi, Arthroleptis carquejai, Rappia (=Hyperolius) nobrei) and some species and varieties that have been subsequently synonymised.

From 1903 to 1905, William John Ansorge collected considerable material in northern, central and southwestern Angola. The collected amphibians are deposited in the British Museum, and were studied by Boulenger (1905, 1907a, b). Arthroleptis (=Phrynobatrachus) parvulus, Arthroleptis xenochirus, Rana (=Ptychadena) ansorgii, Rana (=Tomopterna) cryptotis, and Rana (=Ptychadena) bunoderma were all described from this material.

A number of expeditions in Angola included herpetological surveys, and had their reptiles studied, but the amphibians were not reported. Examples of this are the Rohan-Chabot Mission (1912-1914), which explored the south of Angola and had its specimens deposited in the Paris Natural History Museum, and the Vernay Angola Expedition (1925), from which the large collection is housed in the American Museum of Natural History.

Analysing material from the Berlin Zoological Museum, Ahl (1925) described Hylarthroleptis (=Phrynobatrachus) brevipalmatus from Angola, and several species of reed frogs, two of which are endemic to Angola (Hyperolius bicolor, Hyperolius gularis) and others which have later been synonymised into larger species complexes such as Hyperolius parallelus complex (H. angolensis, H. huillensis, H. microstictus), Hyperolius marmoratus complex (H. decoratus, $H$. marungaensis), and Hyperolius platyceps complex (H. angolanus).

In 1930-1931, the Pulitzer-Angola Expedition surveyed southwestern and central areas of the country. Over 400 specimens of amphibians were collected and deposited in the Carnegie Museum, in the United States of America. These were studied by Karl Patterson Schmidt (1936), who reported on 17 species. Although no new species were described, some were synonymised and others revived from synonymy leading the author to highlight the importance of understanding the Angolan fauna for clarifying African amphibian taxonomy.

During two trips to central and southern Angola (1928-1929 and 1932-1933) Albert Monard made important collections of amphibians and reptiles, as well as other groups. The herpetological material was deposited in the La Chaux-de-Fonds Museum, Switzerland. Monard (1937) provided an updated compilation of Angolan amphibians with a revision of the existing literature (including Ahl, Bocage, Boulenger and Schmidt's publications), as well as his own findings. Five new species of frog were described: Hyperolius cinereus, Cassiniopsis (=Kassina) kuvan- 
gensis, Rana (=Ptychadena) keilingi, Hyperolius erythromelanus, Rana (=Ptychadena) buneli, the last two now considered synonyms of $H$. paralleus and Ptychadena bunoderma, respectively. In total, 80 species of amphibians were mentioned, meaning that in the four decades since Bocage's (1895a) first synthesis the known frog species for Angola had doubled.

In 1933-1934, Karl Jordan's expedition to South West Africa (now Namibia) and Angola surveyed localities on the Angolan escarpment (Congulo and Quirimbo) and afromontane forest (Mount Moco) (Jordan 1936). This material is deposited in the British Museum and the herpetofauna studied by Parker (1936). One new species of treefrog (Leptopelis jordani) and a new subspecies of white-lipped frog (Rana (=Amnirana) albolabris acustirostris) were described from this expedition. As the name acustirostris was preoccupied, Mertens (1938b) proposed the replacement name Rana (=Amnirana) albolabris parkeriana, which was later elevated to a full species by Perret (1977). Both these species remain known only from their type localities, and are escarpment-endemics.

In the 1930s W Schack visited Angola and made a collection of amphibians which were deposited in the Natur-Museum Senckenberg, Frankfurt, and studied by Mertens (1938a), who recorded only eight species, none of which was new.

In 1952-1954, within the scope of the Hamburg Museum expeditions, GA von Maydell made significant herpetological collections from north to south of Angola. The reptiles were studied by Walter Hellmich (1957a), but the amphibians have never been studied until recently (Ceríaco et al. 2014b). Hellmich made a trip to the Angolan region of Entre-Rios, and reported on new localities for frog species (Hellmich 1957b), also commenting on the Angolan biogeography.

From 1957 to 1959, the Portuguese Mission of Apiarian Studies of the Overseas collected amphibians especially in central and eastern Angola (Luando and Cameia), which were deposited in the Zoology Center of the Institute of Tropical Scientific Research, in Lisbon. These were studied only decades later, by Clara Ruas (1996, 2002).

Raymond F Laurent worked extensively on the herpetofauna of the Congo Basin. He studied material from Museu do Dundo, Lunda-Norte, including the extensive collection made in southwestern Angola by the Museum Director, António Barros Machado. During this period, he recorded several new frogs for Angola (Laurent 1950, 1954, 1964), and described four new species (Ptychadena grandisonae, $P$. guibei, P. perplicata and Hyperolius vilhenai).

In 1971 and 1974, Wulf Haacke, from the then Transvaal Museum, South Africa, made two trips to Angola to search mainly for geckos, but incidentally collecting amphibians that were later studied by John Poynton (Poynton and Haacke 1993).

Until the 1970s, zoological expeditions surveyed mostly southwestern and central parts of the country, which were more easily accessible than the inland plateau and the moist forests of the north. Herpetological knowledge about the northeastern region was greatly improved by Laurent's studies. The most poorly studied areas of Angola remained the northwest (the region of Zaire and Uíge provinces, and northern Malange, Bengo, and Cuanza-Norte provinces), followed by the southeastern 'lands at the end of the world', a commonly used expression that refers to the very remote and extensive regions of Moxico and Cuando Cubango provinces. 


\section{Recent History and Increase of Information}

For almost three decades, in the period between Angola's independence and the end of the civil war (1975-2002), the country's instability precluded virtually all field surveys. Every amphibian publication dating from this period involved taxonomic revisions based on existing literature and museum collections, e.g. Perret's (1976) revision of the amphibians, particularly types, deposited in the Lisbon Museum of Natural History. This has become an extremely valuable work given the subsequent loss of these important specimens following the fire that destroyed the museum in 1978.

A key for the identification of Angolan amphibians mainly based on literature revision, including all the species listed for Angola at the time, was published (Cei 1977). With dichotomous keys, drawings, and insights on the Angolan amphibian biogeography, it was intended to make Angolan amphibian identification more accessible to the general public and particularly to students. Poynton (1964) published a faunal study of the southern African amphibians, which referred to Angolan material. This was later updated from 1985 to 1991, when Poynton \& Broadley published Amphibia Zambesiaca, a series of papers (Poynton and Broadley 1985a, b, 1987, 1988, 1991) that addressed in detail all the amphibian families occurring in the Zambezi drainage region, including many that extend into Angola. The publication of a toponymic index of the zoological collections made in Angola (CrawfordCabral and Mesquitela 1989) was a valuable contribution to the study of vertebrates of the country. It provided an overview of the zoological collections performed in Angola and studies related to these expeditions, including a section of type localities and the list of described vertebrates per locality, which lists amphibian species, subspecies and varieties.

In 1993, Poynton \& Haacke described the first new Angolan amphibian species in decades: Bufo (= Pontynophrynus) grandisonae, based on Haacke's expeditions of the 1970s. In 1996, the re-examination of Monard's collection of amphibians from 1928, revealed an 'enigmatic' ranid originally identified as Aubria subsigillata that could not be assigned to any known genus (Perret 1996), but which was later assigned to Aubria masako (Channing 2001) following features described by Ohler (1996). A comprehensive revision of the Angolan amphibians and mapping of each species' distribution based on museum and literature records was made by Ruas (1996), providing taxonomic comments on some species, but not addressing the Hyperoliidae family (then including the current Leptopelinae subfamily). Ruas (2002) described in detail the contents of the amphibian collection deposited in the Zoology Center of the Institute of Tropical Scientific Research in Lisbon, again excluding the Hyperoliidae and Leptopelinae, which are still to be examined. Channing (1999) discussed aspects of Angolan amphibian taxonomy within a southern African historical perspective. Blanc and Frétey (2000) analysed the biogeography, species richness and endemism of the central African and Angolan amphibians, based on the number of species per country. They highlighted the discrepancy in species richness among genera in Angola, with Bufo (currently Mertensophryne, Sclerophrys and Poyntonophrynus), Hyperolius and Ptychadena being the most specious genera, which totalled 42 species, almost half of the species known for the country at the time (86). 
Only in 2009 did Angolan-international collaboration lead to a new era of field surveys, initiated with an expedition to Huíla and Namibe provinces in southwestern Angola. This trip, organised by Brian Huntley, can be considered as a historical landmark for research on Angolan biodiversity. Numerous groups were surveyed (plants, invertebrates, mammals, birds, reptiles and amphibians). A new escarpmentendemic reed frog, Hyperolius chelaensis, was described from Serra da Chela (Conradie et al. 2012), and the colourful ashy reed frog, Hyperolius cinereus Monard 1937 was rediscovered (Conradie et al. 2013). Later in the same year, Alan Channing and Pedro Vaz Pinto surveyed Cangandala National Park and made a trip to Calandula, revisiting this important type locality of several amphibian species, and rediscovered Hyperolius steindachneri Bocage, 1866 in Angola (Channing and Vaz Pinto Unpublished Data). The material obtained from these trips was important for a number of taxonomic revisions. The Angolan river frog Amietia angolensis, previously thought to be widespread in Africa, was found to occur only in Angola (Channing and Baptista 2013; Channing et al. 2016), reed frogs of the Hyperolius nasutus complex (Channing et al. 2013) were shown to include numerous cryptic species, with possibly four occurring in Angola, and the Hyperolius cinnamomeoventris complex was split into different sister clades (Schick et al. 2010).

Another Angolan international expedition, again organised by Brian Huntley in 2011, visited the unexplored Lagoa Carumbo, Angola's second largest freshwater lake, in Lunda Norte province. Preliminary findings revealed a complex herpetofauna (Branch and Conradie 2015), with the description of the new Hyperolius raymondi (Conradie et al. 2013), and the addition of two new country records: Amnirana cf. lepus and Hyperolius pardalis.

Two books, Treefroogs of Africa (Schiøtz 1999) and Amphibians of Central and Southern Africa (Channing 2001) address the Angolan territory, providing species identification keys, colour photographs, and distribution maps. In 2011, a book on the central African and Angolan amphibians was released (Frétey et al. 2011). It addressed Angolan fauna only briefly, providing a species list (without discussion), and synthesis of species and habitat/biogeographical associations. In Tadpoles of Africa (Channing et al. 2012), the larvae of several species occurring in the country are described, and the description of Leptopelis anchietae and Ptychadena porosissima tadpoles are based on Angolan specimens. The popular book Frogs of Southern Africa - A Complete Guide (Du Preez and Carruthers 2009, 2017) provides descriptions of species, morphology, distribution, behaviour, and has advertisement calls available for many species. It has been recently updated to a cell phone app. "Frogs of Southern Africa" and has relevant information about species that also occur in Angola.

In 2012 and 2013, studies of the lower catchments of the Cubango, Cuito and Cuando rivers in southeastern Angola were organised by the Southern Africa Regional Environmental Program (SAREP), funded by the USAID, and included herpetological surveys. Preliminary results have been published (Brooks 2012, 2013), as well as an annotated checklist of the herpetofauna of the region (Conradie et al. 2016).

In 2013, a partnership between the Kimpa Vita University in Uíge, the Technical University Dresden and Senckenberg Natural History Collections, Dresden, promoted herpetological surveys in the extremely poorly known Serra do Pingano eco- 
system and surrounding forest fragments in Uíge Province. Two forest species, Trichobatrachus robustus and Xenopus andrei, typical of the Congo Basin, were added to the country's list (Ernst et al. 2014, 2015). Both these observations represented southern range extensions of hundreds of kilometers. Additional important discoveries from this survey await formal publication, and will certainly increase current knowledge of the taxonomy and biogeography of Angolan amphibians, as well as highlight the exceptional biodiversity of northern Angola (Ernst pers. comm.).

Since 2013, a project of the California Academy of Sciences in collaboration with the National Institute of Biodiversity and Conservation Areas (INBAC), Angola, initiated a study of the Angolan herpetofauna, including the development of an atlas of the Angolan amphibians and reptiles, based on literature, analysis of museum collections from several countries, and new findings (Marques et al. 2014, 2018). The Angolan type material deposited in the Porto Museum was studied, and the nomenclature and taxonomy of hyperoliids, Leptopelis and Arthroleptis described by Ferreira were discussed (Ceríaco et al. 2014a). Analysis of amphibians collected in the Capanda Dam surroundings in Malanje (Ceríaco et al. 2014a) included a possible record of Kassina maculosa, which if confirmed would be the first for the country. In a study of the Namibe Province herpetofauna, Tomopterna damarensis was recorded for the first time for Angola (Ceríaco et al. 2016a; Heinicke et al. 2017), and a new species of pygmy toad has been described from Serra da Neve (Ceríaco et al. 2018a). A booklet on the herpetofauna of the Cangandala National Park in Malanje (Ceríaco et al. 2016c) was also released, followed by a scientific publication on the same subject (Ceríaco et al. 2018b). Research on the project's findings and surveys to additional regions in Angola are ongoing.

In 2015 the Wild Bird Trust, supported by the National Geographic Society, organised Angolan expeditions associated with the Okavango Wilderness Project. Herpetological surveys took place in the headwaters of the Cuito, Cuanavale, Cubango and Cuando rivers and other river sources in the region in both wet and dry seasons. Whilst some of these results have been published (Conradie et al. 2016), the project is ongoing but already two new country records (Kassinula wittei and Leptopelis cf. parvus), numerous range extensions for Angolan herpetofauna, and a number of candidate new species of amphibians have been identified.

Within the Southern African Science Service Centre for Climate Change and Adaptive Land Management (SASSCAL) project, research on herpetology is being undertaken by the Instituto Superior de Ciências da Educação (ISCED)-Huíla. Observatories have been implemented in Tundavala, Bicuar National Park, Cameia National Park, Iona National Park, Candelela and Cusseque (Jürgens et al. 2018). Opportunistic surveys of herpetofauna are made at all observatories (SASSCAL ObservationNet 2017), herpetofauna monitoring has been carried out at the Tundavala observatory since 2016 (Baptista et al. 2018), and a checklist of Bicuar National Park herpetofauna compiled (Baptista et al. in press). Additionally, in collaboration with Fundação Kissama, herpetological surveys have been made at several sites in Huíla Province, and throughout Angola, with emphasis along the Angolan escarpment: Cuanza-Norte, Cuanza-Sul (Cumbira) and Huíla Provinces. An Angolan herpetofauna archive is being developed at ISCED Huíla, and research undertaken in conjunction with these projects. 


\section{International and National Resources}

Given the scarcity and the difficulties in obtaining information about Angolan amphibians, the compilation and listing of existing information sources is relevant. Table 12.1 lists generalist on-line platforms with relevant information about amphibians that include Angolan species, as well as a list of institutions known to have significant Angolan material in their assets.

\section{The Current State of Knowledge on Angolan Amphibians}

Despite some progress made during the last decade, the Angolan herpetofauna remains one of the most poorly known in Africa (Conradie et al. 2016). This lack of information becomes more evident when contrasted with the comprehensive information compilations regarding adjacent Namibia, which include updated lists of species (Herrmann and Branch 2013) and analysis of habitat availability, species richness and conservation (Curtis et al. 1998). For Angola, even basic information, such as accurate species checklists for the country, is absent. Existing information is scattered in recent and historical publications, many of which are not easily accessible. The recent Atlas of Angolan herpetofauna (Marques et al. 2018) contributes to filling this gap. Figure 12.1 shows the localities where amphibians have been collected before and after independence. Although recent surveys have filled some gaps, many areas remain unsurveyed. Figure 12.2 depicts some of the amphibian diversity present in Angola.

\section{Checklist of Angolan Amphibians}

Currently only 111 species are recorded from Angola (Appendix). Marques et al. (2018) list 117 species for the country. This discrepancy results from the use of different criteria for synonymies, and of a conservative approach of the present authors not incuding unconfirmed records, which are discussed elsewhere in this chapter. Both these totals are considered to be underestimates, given the country's size and habitat richness, including the southern desert, the tropical northern forests, the unique escarpment and the extensive plateau, many areas of which remain unsurveyed. This becomes more evident when compared with a country of similar size such as South Africa, whose herpetofauna is the best studied in Africa and which is considerably drier and cooler (and therefore less suitable for amphibians) than Angola, and yet it has 128 species (Frost 2018), and new species continue to be discovered (Turner and Channing 2017; Minter et al. 2017). 
Table 12.1 List of relevant websites with information regarding Angolan amphibians, and collections where Angolan amphibian specimens are deposited, according to available literature

\section{On-line platforms and mobile phone apps}

Amphibian Species of the World: http://research.amnh.org/vz/herpetology/amphibia/

AmphibiaWeb http://amphibiaweb.org/

IUCN Red List http://www.iucnredlist.org/initiatives/amphibians

Frogs of Southern Africa https://play.google.com/store/apps/details?id=com.coolideas.

eproducts.safrogs

\section{Collections where amphibians from Angola are deposited}

\begin{tabular}{|c|c|}
\hline \multirow[t]{4}{*}{ Angola } & $\begin{array}{l}\text { Instituto Nacional para a Biodiversidade e áreas de Conservação, Ministério } \\
\text { do Ambiente (INBAC/MINAMB) }{ }^{\mathrm{a}}\end{array}$ \\
\hline & Museu do Dundo (MD) \\
\hline & Museu Nacional de História Natural (Luanda) ${ }^{\mathrm{a}}$ \\
\hline & $\begin{array}{l}\text { Southern African Science Service Centre for Climate Change and Adaptive } \\
\text { Land Management (SASSCAL) / Instituto Superior de Ciências da Educação } \\
\text { da Huíla (ISCED-Huíla)a }\end{array}$ \\
\hline Austria & $\begin{array}{l}\text { Imperial Natural History Museum (K.K. Museum) / Natural History Museum } \\
\text { of Vienna (NHMW) }\end{array}$ \\
\hline France & National Museum of Natural History (Paris) (MNHNP) \\
\hline \multirow[t]{4}{*}{ Germany } & Berlin Zoological Museum (ZMB - Zoologisches Museum) ${ }^{\mathrm{a}}$ \\
\hline & Forschungsinstitut und Naturmuseum Senckenberg (SMF) \\
\hline & Hamburg Museum (ZMH - Zoologisches Museum für Hamburg) \\
\hline & $\begin{array}{l}\text { Senckenberg Natural History Collections Dresden (MTD - Museum für } \\
\text { Tierkunde Dresden) }\end{array}$ \\
\hline \multirow[t]{3}{*}{ Portugal } & $\begin{array}{l}\text { Centro de Zoologia do Instituto de Investigação Científica Tropical, Lisbon } \\
\text { (IICT) }\end{array}$ \\
\hline & Museu de História Natural na Universidade do Porto (MUP) \\
\hline & $\begin{array}{l}\text { Museu Nacional de História Natural e da Ciência, formerly Museu Bocage, } \\
\text { Lisbon (MBL) - collections destroyed on the } 1978 \text { fire }\end{array}$ \\
\hline \multirow[t]{3}{*}{ South Africa } & $\begin{array}{l}\text { Ditsong National Museum of Natural History (formerly Transvaal Museum) } \\
\text { (TMP), Pretoria }\end{array}$ \\
\hline & Port Elizabeth Museum at Bayworld (PEM) ${ }^{\mathrm{a}}$ \\
\hline & South African Institute for Aquatic Biodiversity $(\mathrm{SAIAB})^{\mathrm{a}}$, Grahamstown \\
\hline Spain & Estación Biológica de Doñana (EBD-CSIC), Sevilla \\
\hline \multirow[t]{2}{*}{ Switzerland } & Musée de la Chaux-de-Fonds (LCFM) \\
\hline & $\begin{array}{l}\text { Museum d'histoire naturelle de la Ville de Genève (MHNG - Geneva Natural } \\
\text { History Museum) }\end{array}$ \\
\hline \multirow[t]{2}{*}{ United Kingdom } & Natural History Museum, London (NHMUK, formerly British Museum) \\
\hline & Natural History Museum at Tring \\
\hline \multirow{7}{*}{$\begin{array}{l}\text { United States of } \\
\text { America }\end{array}$} & Carnegie Museum of Natural History (CM), Pittsburgh \\
\hline & California Academy of Sciences (CAS), San Francisco ${ }^{a}$ \\
\hline & American Museum of Natural History (AMNH), New York ${ }^{\mathrm{a}}$ \\
\hline & Academy of Natural Sciences of Philadelphia (ANSP), Philadelphia \\
\hline & Field Museum of Natural History (FMNH), Chicago \\
\hline & $\begin{array}{l}\text { Museum of Comparative Zoology (MCZ), Harvard University, Cambridge, } \\
\text { Massachusets }\end{array}$ \\
\hline & $\begin{array}{l}\text { National Museum of Natural History, Smithsonian Institution (NMNH), } \\
\text { Washington, D.C. }\end{array}$ \\
\hline
\end{tabular}

aindicates the institutions containing specimens from recent (post-1975) surveys 


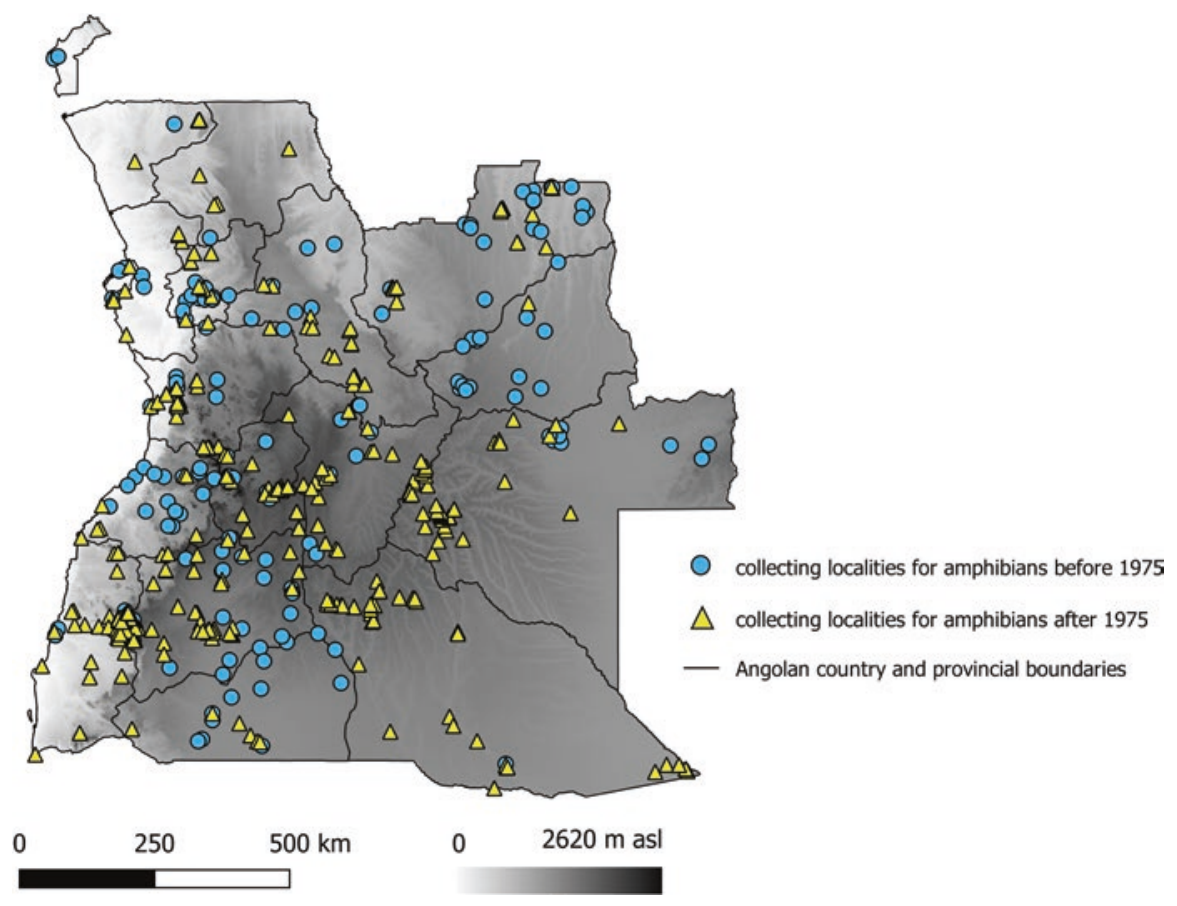

Fig. 12.1 Map with collecting localities for amphibians. Blue circles represent surveys before 1975 (based on literature records), and yellow triangles represent surveys after 1975 (literature records, localities from the 2009 and 2011 expeditions, SAREP and NGOWP trips to southeastern Angola, surveys in the scope of the SASSCAL Project and Fundação Kissama work, and Senckenberg Technical University, Dresden)

\section{Records That Require Confirmation}

A number of unconfirmed records for Angola require further investigation. These include Leptopelis notatus (Laurent 1964), Ptychadena schillukorum (Channing 2001), and Kassina maculosa (Ceríaco et al. 2014a). Monard (1937) noted one specimen of Aubria subsigillata from Caquindo that Perret (1996) could not confidently associate with any known genus, but that Channing (2001) considered to be A. masako. However, the latter is a closed-canopy forest species that is not expected to occur in southern Angola. The stated locality is either in error or the specimen deserves further investigation. Phrynobatrachus dispar was recorded from Cabinda by Peters (1877, as Arthroleptis dispar), but this species originates from São Tomé and Príncipe islands (Uyeda et al. 2007; Frost et al. 2018), and it is therefore likely that the Angolan record refers to another species. Hyperolius nitidulus was also recorded from Angola (Peters 1877), but was described from Nigeria and is currently considered to extend south only to Cameroon (Amiet 2012). Hyperolius ocellatus has been described both from Angola and Fernando Pó, but the type locality was later restricted to Fernando Pó (Perret 1975) which leaves Angolan specimens 

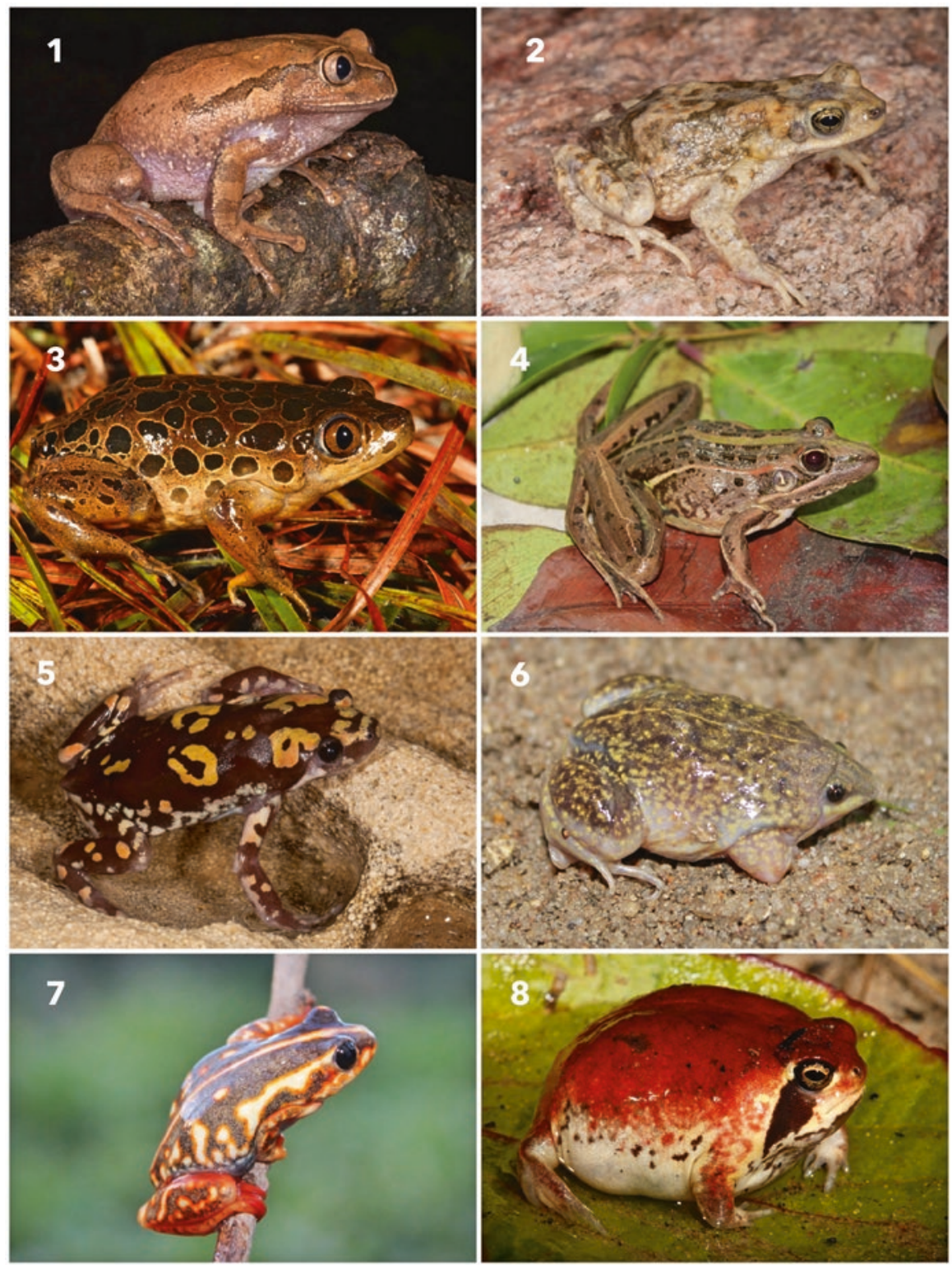

Fig. 12.2 Representative of some of the families of frogs present in Angola. 1 Congulo Forest Tree Frog (Leptopelis jordani) from Congulo. 2 Dombe Pigmy Toad (Poyntonophrynus dombensis) from Meva. 3 Kuvango Kassina (Kassina kuvangensis) from Cuanavale River Source. 4 Spotbellied Grass Frog (Ptychadena subpunctata) from Cameia National Park. 5 Marbled Rubber Frog (Phrynomantis annectens) from Meva. 6 Marbled Snout-Burrower (Hemisus marmoratus) from Bicuar National Park. 7 Angolan Reed Frog (Hyperolius cf. parallelus) from Quilengues. 8 Rain frog (Breviceps sp. nov.) from Cuando River Source. (Photo credits - N Baptista: 4,6,7; P Vaz Pinto: 1,2,5; W Conradie: $\mathbf{3 , 8}$ ) 
with no appliable name. Phrynobatrachus auritus was recorded from Cabinda by Peters (1877) as Arthroleptis plicatus, but the validity of this synonymy for Cabinda requires further study. A number of species recorded from Angola were presumably misidentified as the currently known species' range does not include Angola, including: Phrynobatrachus minutus recorded by Ruas (1996), but which is now restricted to Ethiopia; Hyperolius microps recorded by Bocage (1895) and Monard (1937), now restricted to Eastern Africa; Hyperolius multifasciatus Ahl 1931 which was included provisionally by Monard (1937), but placed in the synonymy of H. kivuensis Ahl 1931, by Pickersgill (2007); and Xenopus calcaratus recorded by Peters (1877), but now restricted to western Africa. Specimens of Ptychadena cf. aequiplicata, which occurs approximately $50 \mathrm{~km}$ from the Cabinda Enclave (Nagy et al. 2013), exist in the AMNH collection, but their identity requires confirmation (Ernst pers. comm.).

\section{Species Likely to Occur in Angola But Not Yet Recorded}

The ranges of many species occurring in adjacent countries (Namibia, Zambia and the Democratic Republic of the Congo, DRC) are likely to extend into Angola and are discussed below. A significant example is that of caecilians (Order Gymnophiona), which are known from the Congo Basin but have not been recorded in Angola, including Cabinda. Species that have been recorded close to the Angolan border and that are likely to occur in the country are listed below.

\section{Caecilians (Gymnophiona)}

The Gaboon Caecilian (Geotrypetes seraphini (Duméril, 1859)) and the Congo Caecilian (Herpele squalostoma (Stutchbury, 1836)) have both been recorded from the extreme western DRC, in Mayombe, River Minkala, Vemba-Minionzi, around Kidima, around $40 \mathrm{~km}$ from the Angolan border (Scheinberg and Fong 2017), and are likely to occur in this poorly known region.

\section{Frogs and Toads (Anura)}

Arthroleptidae

Cryptic Tree Frog (Leptopelis parbocagii Poynton and Broadley, 1987). This tree frog occurs in northern Mwinilunga district, northwest Zambia, less than $50 \mathrm{~km}$ from Cazombo, eastern Angola (Schiøtz and Van Daele 2003), and may occur on the Angolan side of the border. 


\section{Breviciptidae}

Power's Rain Frog (Breviceps poweri Parker, 1934). This rainfrog was found in southwestern Zambia, less than $100 \mathrm{~km}$ from the Angolan border (Pietersen et al. 2017), and can be expected in Angola.

\section{Bufonidae}

Beira Pygmy Toad (Poyntonophrynus beiranus (Loveridge, 1932)). Recorded from southwestern Zambia near the Angolan border (Poynton and Broadley 1991) and may occur in Angola.

Northern Pygmy Toad (Poyntonophrynus fenoulheti (Hewitt and Methuen, 1913)). This pigmy toad is recorded from Caprivi Strip in northeastern Namibia (Channing and Griffin 1993) and southwestern Zambia (Pietersen et al. 2017), less than $100 \mathrm{~km}$ from the Angolan border, and its presence is expected in southeastern Angola.

\section{Hemisotidae}

Perret's Snout-burrower (Hemisus perreti Laurent, 1972). Recorded in Singa Mbamba, Mayumbe (Royal Museum for Central Africa 2017) and in the region of Kipanzu, Tshela (MHNG 2017) both in the Bas-Congo Province, DRC, in close proximity to the Cabinda enclave, and it is therefore expected to occur in Cabinda.

Barotse Snout-burrower (Hemisus barotseensis Channing and Broadley 2002). Described from the Barotse floodplain near Mongu, in southwestern Zambia, $120 \mathrm{~km}$ east of the Angolan border, but may occur in suitable floodplain habitat along the eastern Zambezi drainage.

\section{Hyperoliidae}

Foulassi Spiny Reed Frog (Afrixalus paradorsalis (Perret, 1960)). This hyperoliid was found in Luango-Nzambi, DRC, around $50 \mathrm{~km}$ from the Cabinda Enclave (Nagy et al. 2013) and is likely to occur in Angola.

Rainforest Reed Frog (Hyperolius tuberculatus (Mocquard, 1897)). Also found in Luango-Nzambi, DRC (Nagy et al. 2013) and likely to occur at least in Cabinda.

Kachalola Reed Frog (Hyperolius kachalolae Schiøtz, 1975). Known from Mwinilunga district, in northwestern Zambia (Schiøtz and Van Daele 2003), less than $50 \mathrm{~km}$ from the eastern Angolan border.

Hyperolius major Laurent, 1957. This reed frog occurs in Mwinilunga district, in northwestern Zambia, less than $50 \mathrm{~km}$ of Cazombo (Poynton and Broadley 1991; Schiøtz and Van Daele 2003), eastern Angola. 
Phrynobatrachidae

Golden Puddle Frog (Phrynobatrachus auritus Boulenger, 1900). This species of puddle frog was found in Luki, DRC, only $20 \mathrm{~km}$ north of Angola (Nagy et al. 2013) and may occur in the country.

Horned Puddle Frog (Phrynobatrachus sp. aff. cornutus (Boulenger, 1906)), also found in Luki, DRC (Nagy et al. 2013) and likely to occur in Angola.

\section{Pipidae}

Gaboon Dwarf Clawed Frog (Hymenochirus sp. aff. feae Boulenger 1906), and Xenopus (Silurana) sp. This Dwarf Clawed Frog and an unidentified species of clawed frog were found in Luki, DRC, $20 \mathrm{~km}$ north of the Angolan border (Nagy et al. 2013) and are expected in Angolan territory.

Fraser's Clawed Frog (Xenopus cf. fraseri Boulenger, 1905). This clawed frog has been found in Luki, DRC, $20 \mathrm{~km}$ north of the Angolan border (Nagy et al. 2013) and is expected in Angola, although the records of these species are considered to need a critical revision (Ernst et al. 2015).

Common Platanna (Xenopus laevis (Daudin, 1802)). Recorded in Luki, DRC, $20 \mathrm{~km}$ north of the Angolan border, and in Tsumba-Kituti (Nagy et al. 2013) and might occur in Angola.

Ptychadenidae

Dark Grass Frog (Ptychadena obscura (Schmidt and Inger, 1959)). This species has been recorded in the Ikelenge pedicle, northern Mwinilunga district, northwestern Zambia, in close proximity to the Angolan eastern border (Poynton and Broadley 1991).

Mapacha Grass Frog (Ptychadena cf. mapacha Channing, 1993). This Grass Frog is described from the Caprivi Strip in Namibia, near southeastern Angola (Channing 1993). It has also been recorded about $80 \mathrm{~km}$ east of Rundu (Haacke 1999), near Vicota, around $30 \mathrm{~km}$ south of the Angolan border (Ceríaco et al. 2016a), and in southwestern Zambia (Pietersen et al. 2017). Conradie et al. (2016) collected a series of Ptychadena at Jamba provisionally assigned to $P$. cf. mossambica, but mentioned that the specimens might be referable to $P$. mapacha. All these records suggest that this species may occur in southeastern Angola.

Perret's Grass Frog (Ptychadena cf. perreti Guibé and Lamotte, 1958). This grass frog was found in Nkamuna, in the Bas-Congo province of DRC, near Angola (Nagy et al. 2013). 


\section{Pyxicephalidae}

Boettger's Dainty Frog (Cacosternum boettgeri (Boulenger, 1882)). This species has been recorded near the Angolan border in northern Namibia in Caprivi Strip and in Omusati province (Channing and Griffin 1993), and Southern Province in Zambia (Broadley 1971) and may occur in Angolan territory.

Knocking Sand Frog (Tomopterna krugerensis Passmore and Carruthers, 1975). This frog has been recorded in northern Namibia close to the Angolan border (Channing and Griffin 1993).

Tandy's Sand Frog (Tomopterna tandyi Channing and Bogart, 1996). Recorded from northern Namibia near the Angolan border (Coetzer 2017), and may occur in southwestern Angola. A recent fing of Tomopterna has been made in Bicuar National Park and its identification as T. tandyi is under discussion (Baptista et al. in press).

\section{Rhacophoridae}

Southern Foam Nest Frog (Chiromantis xerampelina Peters, 1854). Recorded from Caprivi Strip in northern Namibia (Channing and Griffin 1993) and from southeastern Zambia (Broadley 1971; Pietersen et al. 2017), and therefore expected in southeastern Angola. It is recorded from southwestern Angola (Schiøtz 1999), but the original source of this record is unknown. This odd distribution record requires confirmation.

Western Foam-nest Tree Frog (Chiromantis rufescens (Günther, 1869)). This species is known from near Boma, close to the northern bank of the Congo River (Royal Belgian Institute of Natural Sciences 2017) and may occur in Angola.

According to Frost (2018), based on distribution and species' habitat affinities, around 20 additional species are expected in the country, mostly from the northern forests and expected in the Cabinda enclave in northern Angola. These are generalist assumptions that do not necessarily take into account actual proximity to the Angolan border. These include arthroleptids Silver Long-fingered Frog (Cardioglossa leucomystax (Boulenger, 1903)), Kala Forest Treefrog (Leptopelis aubryioides (Andersson, 1907)), Victoria Forest Treefrog (Leptopelis boulengeri (Werner, 1898)), Red Treefrog (Leptopelis rufus Reichenow, 1874)); bufonids [High Tropical Forest Toad (Sclerophrys latifrons (Boulenger, 1900))], hyperoliids [African Wart Frog (Acanthixalus spinosus (Buchholz and Peters, 1875)); Greshoff's Wax Frog (Cryptothylax greshoffii (Schilthuis 1889) with an unconfirmed record from northwestern Angola (Schiøtz 1999)), Olive Striped Frog (Phlyctimantis leonardi (Boulenger, 1906), ptychadenids [Savanna Grass Frog (Ptychadena superciliaris (Günther, 1858)], and pipids [Western Dwarf Clawed Frog (Hymenochirus curtipes Noble, 1924), False Fraser's Clawed Frog (Xenopus allofraseri Evans, Carter, Greenbaum, et al., 2015)]. 


\section{Hidden Among the Unknown - Angolan Tadpoles}

An important and often neglected component of studying amphibians is knowledge of their larvae. Unlike adult frogs, whose activity is quite dependent on appropriate weather conditions, breeding season, and nocturnal activity for most species, tadpoles can be easily found in water bodies, during the day, and throughout the year in some cases. The study of tadpoles includes not only morphology, but also microhabitat requirements, ecology, behaviour, feeding habits, predator-prey interactions, etc. Although they look similar at first glance, tadpole morphology usually allows the identification to genus, and a more precise analysis can often lead to species identification.

Early literature regarding southern African tadpoles often covers species occurring in Angola (Van Dijk 1966, 1971). Channing et al. (2012) provide a comprehensive review of the knowledge about African tadpoles with keys to the identification of genera and detailed description of species. Given the poorly known status of Angolan amphibians, it is not surprising that very little is known about Angolan tadpoles. Out of the 99 Angolan species that have tadpoles (i. e., Breviceps and Arthroleptis genera not included), the tadpoles of only 44 species have been described, and only those of Ptychadena porosissima (Channing et al. 2012), Amietia angolensis (Channing et al. 2016) and of the recent discoveries of the endemic Hyperolius chelaensis (Conradie et al. 2012), H. cinereus and H. raymondi (Conradie et al. 2013) are based on Angolan material. A recent description of Leptopelis anchietae tadpoles is also based on Angolan material (Channing et al. 2012), but it was not encountered with adult specimens, and was based on the association with the first description of that tadpole (Lamotte and Perret 1961), which was based on a specimen from Cameroon that may involve another species. A list of the Angolan frogs with undescribed tadpoles (Table 12.2) includes some of the more common local species.

\section{Comments on Selected Groups}

As a consequence of the current poor knowledge of Angola's amphibians, the taxonomic status of many species in the checklist remains unresolved. Some of these are discussed in this section, as well as recent discoveries from ongoing studies.

\section{Species Complexes and Species with Unclear Boundaries}

Some morphologically similar species display variation in calls or habitat and are considered to form a complex of closely-related species, and the resolution of their taxonomic status and distribution requires comprehensive investigation. This is 
exemplified by the Hyperolius marmoratus/viridiflavus complex in Africa, in which 15 names from Angola have been synonymised (Hyperolius cinctiventris, $H$. decoratus, $H$. huillensis, $H$. insignis, $H$. marungaensis, $H$. microstictus, $H$. pliciferus, H. vermiculatus, Rappia cinctiventris, R. marmorata marginata, $R . m$. paralella, $R$. m. variegata, $R$. plicifera, $R$. toulsonii, H. m. alborufus). Hyperolius parallelus is closely related to this complex, and has several Angolan taxa in its synonymy $(H$. angolensis, $H$. marmoratus var. angolensis, $H$. erythromelanus, $H$. toulsonii, Rappia marmorata huillensis, $R$. m. insignis, $R$. m. taeniolata). Other difficult groups are the Hyperolius platyceps complex, with four names currently subsumed within it (Hyperolius angolanus, Rappia platyceps var. angolensis,

Table 12.2 Angolan frog species with undescribed tadpoles

\begin{tabular}{|c|c|}
\hline Leptopelis bocagii (Günther, 1865) & Hyperolius platyceps (Boulenger, 1900) \\
\hline Leptopelis cynnamomeus (Bocage, 1893) & Hyperolius polli (Laurent, 1943) \\
\hline Leptopelis jordani (Parker, 1936) & Hyperolius protchei (Rochebrune, 1885) \\
\hline Leptopelis marginatus (Bocage, 1895) & Hyperolius quinquevittatus (Bocage, 1866) \\
\hline Leptopelis parvus (Schmidt and Inger, 1959) & Hyperolius rhizophilus (Rochebrune, 1885) \\
\hline \multirow{2}{*}{$\begin{array}{l}\text { Mertensophryne melanopleura (Schmidt and } \\
\text { Inger, 1959) }\end{array}$} & Hyperolius steindachneri (Bocage, 1866) \\
\hline & Hyperolius vilhenai (Laurent, 1964) \\
\hline Mertensophryne mocquardi (Angel, 1924) & Kassinula wittei (Laurent, 1940) \\
\hline \multirow{2}{*}{$\begin{array}{l}\text { Poyntonophrynus grandisonae (Poynton and } \\
\text { Haacke, 1993) }\end{array}$} & Phrynomantis affinis (Boulenger, 1901) \\
\hline & Phrynobatrachus brevipalmatus (Ahl, 1925) \\
\hline $\begin{array}{l}\text { Poyntonophrynus kavangensis (Poynton and } \\
\text { Broadley, 1988) }\end{array}$ & $\begin{array}{l}\text { Phrynobatrachus cryptotis (Schmidt and } \\
\text { Inger, 1959) }\end{array}$ \\
\hline \multirow{2}{*}{$\begin{array}{l}\text { Poyntonophrynus pachnodes. (Ceríaco, } \\
\text { Marques, Bandeira et al. 2018a) }\end{array}$} & Phrynobatrachus parvulus (Boulenger, 1905) \\
\hline & Xenopus andrei (Loumont, 1983) \\
\hline Sclerophrys buchneri (Peters, 1882) & Xenopus petersii (Bocage, 1895) \\
\hline Afrixalus osorioi (Ferreira, 1906) & \multirow{2}{*}{$\begin{array}{l}\text { Xenopus epitropicalis (Fischberg, Colombelli, } \\
\text { and Picard, 1982) }\end{array}$} \\
\hline Afrixalus fulvovittatus (Cope, 1861) & \\
\hline Afrixalus wittei (Laurent, 1941). & Hildebrandtia ornatissima (Bocage, 1879) \\
\hline Hyperolius adspersus (Peters, 1877) & Ptychadena ansorgii (Boulenger, 1905) \\
\hline Hyperolius benguellensis (Bocage, 1893) & Ptychadena bunoderma (Boulenger, 1907) \\
\hline Hyperolius bicolor (Ahl, 1931) & Ptychadena grandisonae (Laurent, 1954) \\
\hline Hyperolius bocagei (Steindachner, 1867) & Ptychadena guibei (Laurent, 1954) \\
\hline Hyperolius cinnamomeoventris (Bocage, 1866) & Ptychadena keilingi (Monard, 1937) \\
\hline Hyperolius fasciatus (Ferreira, 1906) & Ptychadena perplicata (Laurent, 1964) \\
\hline Hyperolius ferreirai (Noble, 1924) & Ptychadena taenioscelis (Laurent, 1954) \\
\hline Hyperolius fuscigula (Bocage, 1866) & $\begin{array}{l}\text { Ptychadena upembae (Schmidt and Inger, } \\
\text { 1959) }\end{array}$ \\
\hline Hyperolius gularis Ahl, 1931 & Ptychadena uzungwensis (Loveridge, 1932) \\
\hline Hyperolius langi (Noble, 1924) & \multirow{2}{*}{$\begin{array}{l}\text { Tomopterna damarensis (Dawood and } \\
\text { Channing, 2002) }\end{array}$} \\
\hline Hyperolius lucani (Rochebrune, 1885) & \\
\hline Hyperolius maestus (Rochebrune, 1885) & Tomopterna tuberculosa (Boulenger, 1882) \\
\hline Hyperolius nobrei (Ferreira, 1906) & \multirow[t]{2}{*}{ Amnirana parkeriana (Mertens, 1938) } \\
\hline Hyperolius parallelus (Günther, 1858) & \\
\hline
\end{tabular}


Hyperolius fasciatus, Hyperolius ferreirai (originally Rappia bivittata)), and the super-cryptic Hyperolius nasutus complex. Currently this is represented in Angola by at least four species (H. adspersus, H. benguellensis, H. dartevellei, H. nasutus) (Channing et al. 2013) and additional names that have been synonymised (H. punctulatus, Rappia punctulata) (Channing et al. 2013) or not assigned to any known species occurring in Angola (H. microps).

Typical toads are another problematic group. Formerly known as Bufo, which was cosmopolitan in distribution and included the majority of bufonids, the genus was partitioned with African typical toads transferred to Amietophrynus (Frost et al. 2006), and more recently renamed in the reinstated genus Sclerophrys (Poynton et al. 2016). Seven species of typical toad occur in Angola (see Table 12.2). The mysterious S. buchneri, known only from the holotype from northeastern Angola, is considered as a valid species (Frost 2018), but synonymy with S. funerea has been suggested and requires further studies (Tandy and Keith 1972). Apart from S. lemairii which is easily distinguishable morphologically from the remaining species, distinction between the other Sclerophrys is difficult, even between the most common species. Hybridisation between Sclerophrys species has been documented and discussed (Guttman 1967; Passmore 1972; Cunningham and Cherry 2004) and may further complicate identification. The red coloration of the interior thigh and parotid gland development are features commonly used to distinguish the often sympatric S. pusilla, S. gutturalis and S. regularis (Du Preez and Carruthers 2017), but do not distinguish these species in Angola. It is likely that cryptic diversity exists, and understanding of the genus and delimitation of species boundaries requires an integrative approach with comprehensive surveys, analysis of advertisement calls and genetic studies.

Grass frogs, Ptychadena spp., are a challenging genus. At least 15 species of this specious genus are represented in Angola (Appendix). P. mascareniensis, a large species complex widespread in Africa and Madagascar, has been recently partitioned (Dehling and Sinsch 2013b) with Ptychadena nilotica in much of continental Africa, including Angola (Zimkus et al. 2017). Difficulties in distinguishing Ptychadena species have been discussed (Poynton and Broadley 1985b; Dehling and Sinsch 2013a, b), although coloration features such as triangular patch on the head, pattern of the interior thigh (Poynton 1970) and several morphometric and morphological features enable species identification (Dehling and Sinsch 2013a, b). Species distinction in Angola is not clear, and in a recent study as many as six different species of Ptychadena were found in the same region (Conradie et al. 2016).

Rainfrogs in Angola are known from a single species, Breviceps adspersus. However, analysis of material from Angola and adjacent regions has revealed that the Angolan form has features of $B$. mossambicus and may indicate an undescribed Angolan species (Poynton and Broadley 1985a, 1991).

Groups that remain not fully understood such as Phrynobatrachus (Zimkus et al. 2010), Xenopus (Furman et al. 2015) and Amnirana (Jongsma et al. 2018), all have species widespread in Africa with type localities from Angola, and the resolution of their taxonomy depends on detailed studies in Angola. 


\section{Species Synonymised with No Clear Justification}

A number of putative Angolan species currently placed in synonymy require reassessment as they may represent hidden diversity currently placed under a different name. Cases are mentioned in the previous section, especially in the Hyperolius genus. Other examples of this include the placement of Hylambates (=Leptopelis) angolensis in the synonymy of Leptopelis bocagii. This resulted from comparison between adult and juvenile specimens (Perret 1976) that may not be comparable. Hylambates bocagei var. leucopunctata Ferreira 1904, has also been placed in the synonymy of Leptopelis bocagii (Ceríaco et al. 2014b) and this also requires further investigation as the well developed finger pads in the type specimen of $H$. b. leucopunctata suggests an arboreal habit, very different from the ground-dwelling habits of $L$. bocagii, which lacks pads on fingers or toes.

\section{Species with Questionable Distributions}

Some species described from Angola have widespread distributions throughout Africa and inhabit diverse habitats, suggesting that cryptic diversity may be involved (see examples in Endemism section, below). The classic example of this is the Common River Frog, Amietia angolensis, which was considered widespread in the continent, but which was discovered to be in fact a complex of cryptic species, with true $A$. angolensis being restricted to Angola (Channing and Baptista 2013). Another potential example is Afrixalus osorioi, which was described from western Angola and remains known in the country only from the type locality, whereas the closest other records are in DRC, nearly $1000 \mathrm{~km}$ away from the type locality. Other examples include Ptychadena porosissima, Leptopelis cynnamomeus, L. bocagii, Hyperolius bocagei, and highlight the earlier comments that study of Angolan amphibians is crucial for solving many problems in African amphibian taxonomy.

\section{Recent Discoveries and Ongoing Studies}

The endemic Anchieta's Treefrog, Leptopelis anchietae and Congulo Forest Treefrog, Leptopelis jordani have been rediscovered in the Angolan escarpment (Baptista et al. 2017), and together with other frogs belonging to the genus Kassina, Arthroleptis and Amnirana found in the region, their conservation and taxonomic status are being investigated (Baptista et al. in prep.). Further to this, ongoing studies (Baptista et al. in prep.) are assessing: a candidate new species of Schismaderma; the taxonomic status of Hildebrandtia ornatissima from the Angolan central plateau, previously discussed by Boulenger (1919); the status of Hyperolius punctulatus from the Cuanza River (currently in the synonymy of Hyperolius nasutus); and 
the status of various populations of morphologically distinct pygmy toads that cannot be assigned to known Poyntonophrynus species. During the 2011 expedition to Lagoa Carumbo, a large white-lipped frog was morphologically assigned to the Amnirana lepus group (Branch and Conradie 2015). This assigment has been confirmed in a phylogeny of the genus (Jongsma et al. 2018), and further studies are underway to address the taxonomical status of the Angolan population (Conradie pers. comm.). On the SAREP (2012/3) and the NGOWP (2016/7) expeditions to southeastern Angola, numerous candidate new species were discovered, in the genera Phrynobatrachus, Breviceps and Amnirana, and are currently under investigation (Conradie pers. comm.). The new country records of Kassinula wittei and Leptopelis cf. parvus are being studied to determine if they conform to the nominal forms from northern Zambia and southern DRC, respectively (Conradie pers. comm.). During recent independent surveys conducted in the northern Angolan provinces of Uíge (Ernst et al. 2014, 2015) and Zaire (Vaz Pinto and Baptista Unpublished Data), two different Alexteroon spp. were discovered. The taxonomic status of these, the first Angolan records for this poorly-known hyperoliid genus, are under investigation with the Uíge species tentatively assigned to the nominal species A. hypsiphonus, whilst the Zaire discovery has affinities to A. obstetricans. The material awaits formal taxonomic assignment pending analysis of type material.

\section{Biogeography}

Angola is one of the most biogeographically rich countries in Africa (Huntley 1974, 2019). Geomorphologically, the country can be divided into various regions, including the western lowlands of the Coast Belt, the Transition Zone which includes the escarpment, the Marginal Mountain Chain, the Old (Highland) Plateau, also known as central plateau, which progressively decreases in altitude to the east, where the Congo Basin in the north and the Zambezi-Cubango Basin in the south are located (Huntley 1974). Each of these regions have several biome associations, with habitats ranging from the tropical rainforests on the Maiombe region in the north, to the Namib Desert in the south, one of the oldest deserts in the world (Huntley 1974, 2019). This complexity is reflected in the country's diverse fauna.

The difficulties in establishing clear biogeographic regions for amphibians is demonstrated by Poynton and Broadley (1991), in their thorough analysis of the biogeography of the Zambezian amphibians. For Angolan amphibians, which are much more poorly known, this difficulty is immensely increased. The biogeography of Angolan amphibians can only be assessed after major taxonomic issues are resolved, which in some cases requires the revision of entire genera (Cei 1977; Blanc and Frétey 2000). In early studies of the Angolan herpetofauna, several attempts were made to group species according to the distributions known at the time, and these will be summarised below.

Bocage (1895a) made the first grouping, distinguishing a northern and southern region, each divided into coastal, intermediate and high-altitude zones, and listing 
species occurring in each block. Monard (1937) used humidity to explain the higher diversity of amphibian species in central Angola (a high-rainfall region), compared to the south. He divided Angolan amphibians into four groups: (i) pan-African species (4\% of the country's species; such as Rana mascareniensis (=Ptychadena nilotica), and Bufo (=Sclerophrys) regularis; (ii) southern species (10\%) which reached their northern limit in Angola, such as Pyxicephalus adspersus; (iii) tropical species (40\%), from western, central and eastern Africa, highlighting the central African tropics as the most significant influence, and including Rana (=Amnirana) albolabris and Rana (=Hoplobatrachus) occipitalis; and (iv) endemic species (46\%), most of which are no longer considered endemic (see Endemism section).

Based on the species known from Angola at the time, Cei (1977) organised Angolan amphibians in three questionable groups, each with affinities to different habitats and regions: (i) the northern and northeastern forests and savannas, (ii) the plateau, and (iii) the arid and semi-arid regions of the coast and of the south, providing a map to delineate those areas. The first area is wide, with northern and northeastern limits in the Congo, Cuanza and Cassai rivers (in Zaire, Uíge, Malanje and Lunda-Norte), and extending to the southeast through Moxico and Cuando Cubango. Examples of species within this group are Arthroleptis carquejai and Hyperolius steindachneri. The second region corresponds to the south of Congo and Cuango rivers and comprises the southern tropics: Cuanza-Norte, Cuanza-Sul, Huambo, Bié, Malanje and Huíla provinces. Characteristic species in this group include Hildebrandtia ornatissima, Hyperolius cinereus, Hyperolius quinquevittatus, Leptopelis anchietae. The third and southernmost region comprises the arid sections of Benguela, Namibe, and Cunene provinces. The fauna on this group is related to that of the Namib, Kalahari, and Namaqualand regions, and can be exemplified by Pyxicephalus adspersus and Poyntonophrynus dombensis.

Surprisingly, the Great Escarpment of Angola has not been considered in any of these studies. This escarpment is part of a much larger geomorphological unit that dominates the African subcontinent and extends into western Angola, where it acts as a barrier between the dry coastline and the inland plateau. Due to its climatic and topographic peculiarities, it promotes isolation and thus speciation (Huntley 1974). It is a well-documented center of endemism for birds (Hall 1960), and although the escarpment herpetofauna is poorly understood, its endemism potential for herpetofauna has been highlighted (Laurent 1964, Clark et al. 2011, Baptista et al. 2018, Branch et al. 2019), and endemic amphibian species are known from the region (Leptopelis jordani, L. marginatus, Amnirana parkeriana and Hyperolius chelaensis). Bordering the Angolan escarpment to the east, the highlands of the ancient massif include patches of Afromontane forest. These consist of islands of relic cool moist Afromontane forest with great biogeographic interest (Huntley 1974), and also potential for endemism.

Inland to the escarpment zone, the plateau is broadly dominated by miombo woodlands, and its fauna often has influences from adjacent regions. Boundaries between regions are not always clear or well understood. Some of these uncertainties have been mentioned in early studies and still require explanation. Hellmich (1957b) referred to the difficulty in establishing geographical limits between the 
moist forests of the north and the central plateau. An example of this is the penetration of forest species in association with riverine habitats along the northern rivers of Angola. He also noted that faunal boundaries between the slopes of the eastern plateau and the flatlands between Cassai and Cuando were not clear, with the presence of 'pockets' of herpetological elements typical of the south on the central plateau. Laurent (1964) referred to the known affinities between the species of Katanga, in southeastern DRC, with the species of the Lundas and Moxico in Angola.

All of these early biogeographic regions and the species assigned to them need to be re-evaluated with updated taxonomy, accurate species distributions, and in association with the study of phylogenetic relationships among the various amphibian families and genera occurring in Angola. The confirmation of ancestral relationships within these groups is a prerequisite for testing hypotheses about the timing and environmental correlates of amphibian movement and speciation across the Angolan landscape.

\section{Endemism}

The originality of the Angolan amphibians due to the richness of endemic species has been highlighted (Blanc and Frétey 2000). Angola's more unique amphibians are also the most poorly known. There are 21 species of amphibians endemic to Angola, of which about $75 \%$ are only known from the type locality or type specimens (Table 12.3). Many have not been found for decades, and in some cases for over 100 years. Most of these species are classified as Data Deficient in the IUCN Red List (IUCN 2017).

A number of endemic taxa have been mentioned in the literature but still await formal description: Hyperolius sp. I, Hyperolius sp. II, Hyperolius sp. III (Monard 1937), possibly unknown genus (Perret 1996), and as the taxonomic studies on Angolan amphibians progress, more endemic species will very likely be discovered. In contrast, many early species that were considered endemic have now been relegated to the synonymy of wide-ranging species. Monard (1937), for instance, considered nearly half $(46 \%)$ of the 80 Angolan species he considered to occur in the country as endemic. However, of the 37 endemic species he identified, only eight are still recognised. Sixteen of these former 'endemics' have been synonymised with other species; e.g. Leptopelis angolensis (= L. bocagii), Rana buneli (= Ptychadena bunoderma), Hyperolius seabrai $(=H$. bocagei), Hyperolius angolanus, H. ferreirai, H. fasciatus (all =Hyperolius platyceps), $H$. pliciferus, $H$. vermiculatus, H. marungaensis (all =Hyperolus marmoratus), $H$. angolensis, $H$. erythromelanus, $H$. toulsonii (all =Hyperolius parallelus), $H$. punctulatus (=Hyperolius nasutus), Rana myotympanum (=Hildebrandtia ornatissima), Rana cacondana and $R$. signata (=Tomopterna tuberculosa). Many of these synonymies have poor justification, and whilst some names may reflect regional variation, others 
Table 12.3 List of amphibian species endemic to Angola, with IUCN Red List Category ( $L C$ least concern, $D D$ data deficient, $N / A$ not assessed), and marked $(\mathrm{X})$ when known only from the type locality

\begin{tabular}{|c|c|c|c|}
\hline Common name & Scientific name & IUCN & TYPE \\
\hline Angola River frog & Amietia angolensis (Bocage, 1866) & LC & \\
\hline $\begin{array}{l}\text { Parker's white-lipped } \\
\text { frog }\end{array}$ & Amnirana parkeriana (Mertens, 1938) & DD & $X$ \\
\hline Cambondo squeaker & Arthroleptis carquejai (Ferreira, 1906) & DD & $X$ \\
\hline Angola ornate frog & Hildebrandtia ornatissima (Bocage, 1879) & DD & \\
\hline Two-colored reed frog & Hyperolius bicolor (Ahl, 1931) & $\mathrm{DD}$ & $\mathrm{X}$ \\
\hline $\begin{array}{l}\text { Chela Mountain Reed } \\
\text { Frog }\end{array}$ & Hyperolius chelaensis (Conradie et al., 2012) & N/A & $\mathrm{X}$ \\
\hline Monard's Reed Frog & Hyperolius cinereus (Monard, 1937) & $\mathrm{LC}$ & \\
\hline $\begin{array}{l}\text { Brown-throated Reed } \\
\text { Frog }\end{array}$ & Hyperolius fuscigula (Bocage, 1866) & DD & $\mathrm{X}$ \\
\hline Loanda Reed Frog & Hyperolius gularis (Ahl, 1931) & DD & $\mathrm{X}$ \\
\hline Landana Reed Frog & Hyperolius lucani (Rochebrune, 1885) & DD & $\mathrm{X}$ \\
\hline Cabinda Reed Frog & Hyperolius maestus (Rochebrune, 1885) & $\mathrm{DD}$ & $X$ \\
\hline Nobre's Reed Frog & Hyperolius nobrei (Ferreira, 1906) & N/A & $\mathrm{X}$ \\
\hline $\begin{array}{l}\text { Rochebrune's Reed } \\
\text { Frog }\end{array}$ & Hyperolius protchei (Rochebrune, 1885) & DD & $\mathrm{X}$ \\
\hline Raymond's Reed Frog & Hyperolius raymondi (Conradie et al., 2013) & N/A & \\
\hline African Reed Frog & Hyperolius rhizophilus (Rochebrune, 1885) & $\mathrm{DD}$ & $\mathrm{X}$ \\
\hline Luita River Reed Frog & Hyperolius vilhenai (Laurent, 1964) & DD & $\mathrm{X}$ \\
\hline $\begin{array}{l}\text { Congulo Forest } \\
\text { Treefrog }\end{array}$ & Leptopelis jordani (Parker, 1936) & DD & $\mathrm{X}$ \\
\hline $\begin{array}{l}\text { Quissange Forest } \\
\text { Treefrog }\end{array}$ & Leptopelis marginatus (Bocage, 1895) & DD & $\mathrm{X}$ \\
\hline Ahl's Puddle Frog & Phrynobatrachus brevipalmatus (Ahl, 1925) & DD & $\mathrm{X}$ \\
\hline $\begin{array}{l}\text { Grandison's Pygmy } \\
\text { Toad }\end{array}$ & $\begin{array}{l}\text { Poyntonophrynus grandisonae (Poynton and Haacke, } \\
\text { 1993) }\end{array}$ & DD & $\mathrm{X}$ \\
\hline $\begin{array}{l}\text { Serra da Neve Pygmy } \\
\text { Toad }\end{array}$ & $\begin{array}{l}\text { Poyntonophrynus pachnodes (Ceríaco, Marques, } \\
\text { Bandeira et al., 2018a) }\end{array}$ & N/A & $\mathrm{X}$ \\
\hline
\end{tabular}

Taxonomy follows Frost (2018)

referred to species found in other countries may not be conspecific (see Comments on selected groups). All deserve careful re-examination.

At least four species (Leptopelis marginatus, L. jordani, Amnirana parkeriana, and Hyperolius chelaensis) are escarpment-endemics, and others are plateauendemics (Hildebrandtia ornatissima, H. cinereus). However, in order to effectively protect Angolan endemic amphibians and their habitats, further studies are needed to reveal the relations between endemic amphibians and particular habitat, and also the importance of other potential areas of endemism (e.g. relic Afromontane forest patches, isolated mountains such as Serra da Neve, the Angolan escarpment). 


\section{Directions for Future Research in Angola}

Detailed species lists for a country are an essential baseline tool for understanding biodiversity, its distribution and conservation status. The confusing status of Angolan amphibian taxonomy has been discussed in previous sections and demonstrates how studying taxonomy forms the bedrock for resolving the many pressing questions regarding Angolan amphibian conservation and biology.

A critical first taxonomic step is to revisit the type localities of all the species described from the country to obtain new topotypical material. This is particularly important for the 15 species described by Bocage (Amietia angolensis, Hyperolius benguellensis, $H$. cinnamomeoventris, $H$. fuscigula, $H$. quinquevittatus, $H$. steindachneri, Ptychadena anchietae, P. subpunctata, Sclerophrys funerea, Leptopelis anchietae, L. cynnamomeus, L. marginatus, Hildebrandtia ornatissima, Poyntonophrynus dombensis, Xenopus petersii), for which many of the type specimens were lost in the fire that destroyed the collections of the Natural History Museum of Lisbon, and for which the original descriptions are the only available source of information. Possibly also lost are the type specimens of several Angolan endemics described by Rochebrune (Hyperolius lucani, H. maestus, H. protchei, $H$. rhizophilus) (Frost 2018), which have very vague descriptions. For many species, neotypes may need to be designated in order to stabilise their taxonomy. Integrative taxonomic studies, including analysis of genetic material, advertisement calls, adult and larval morphology, habitat associations and natural history are crucial to bring Angolan studies into the new millennium.

Many regions of Angola have never been surveyed for amphibians (see Fig. 12.1). Surveying these areas would greatly improve understanding of amphibian distributions, habitat associations and relative abundance, but are also critical for making assessments on their conservation status in terms of IUCN criteria. Priority areas include the northwestern provinces (Uíge and Zaire), the extensive wetlands of Moxico, the escarpment and the adjacent Afromontane forest patches that are rich in endemic birds (Hall 1960), other vertebrates (Crawford-Cabral 1966; Clark et al. 2011) and also probably amphibians, and for which the urgent need of studies has been highlighted (Laurent 1964; Clark et al. 2011).

The controversial frog from Caquindo (Perret 1996) for which genus assignment lacks consensus (see Records that require confirmation), still has to be recollected and its true affinities resolved. This could enrich Angolan herpetology possibly with a new endemic genus. This begs the question - how much remains to be discovered about Angolan amphibians? It also shows how the analysis of extant collections can contribute significantly to the knowledge of the country's fauna. Collections that remain to be studied include those from the Rohan-Chabot Mission, the Vernay Angola Expedition, and the Leptopelinae and Hyperoliidae from the Portuguese Mission of Apiarian Studies of the Overseas.

Another important step to furthering amphibian knowledge is studying the biology of individual species. Some studies are available for iconic species such as the Dombe Pigmy toad Poyntonophrynus dombensis (Channing and Vences 1999), 
based on individuals from Namibia, and Lemaire's toad Sclerophrys lemairii, the first study of this kind made in Angolan territory (Conradie and Bills 2017). However, this is still missing for many species, and understanding their natural history, reproduction strategies, breeding sites, breeding seasons, behaviour, habitat and microhabitat requirements, both for adults and tadpole stages, are key for an effective planning of species conservation. All of this is even more relevant for the extremely poorly known Angolan endemics.

Conservation-driven studies about Angolan amphibians require awareness of potential threats to biodiversity, particularly those resulting from habitat loss and climate change. Habitat degradation as a result of exploitation of natural resources and associated with industrialisation have increased dramatically in Angola in recent decades and will affect amphibians. The implementation of monitoring programmes are crucial for documenting and understanding this relation. Research about the appearance and effect of global amphibian diseases such as the chytrid fungus (Batrachochytrium dendrobatidis), viruses (Ranavirus spp.), and other pathogens, are lacking in Angola, even though they are threatening amphibians around the world and are reported from neighbouring countries (Greenbaum et al. 2014).

The study of Angolan amphibians is a broad and important component of biodiversity studies, for which many baseline questions remain unanswered, and exciting discoveries are still to be made. This becomes more evident when confronted with the fact that Angolan fauna is among the least studied in Africa. Increasing public awareness about amphibians and their importance is necessary for their conservation, and requires developing local knowledge and expertise, as well as constructing functional amphibian collections in national archives. These are essential steps for understanding and protecting this rich, diverse and ecologically important group. This is even more urgent in an era where an "amphibian decline crisis" is happening around the world (Beebee and Griffiths 2005), and where this decline is known to have major consequences in ecosystem function (Whiles et al. 2006).

Acknowledgements The writing of this chapter was made possible through a convergence of efforts and projects. SASSCAL Project (sponsored by the German Federal Ministry of Education and Research (BMBF) under promotion number 01LG1201M); Conservation Leadership Programme (Project CLP ID: F01245015: Conserving Angolan Scarp Forests: a Holistic Approach for Kumbira Forest); National Geographic/Okavango Wilderness Project (NGOWP); South Africa's National Research Foundation (2009-2017, WRB), National Geographic Society (Explorer Grant 2011, WRB); Fundação para a Ciência e Tecnologia (contract SFRH/PD/ BD/140810/2018, NB); and Wild Bird Trust 2015-2018. Particular thanks go to Fernanda Lages (ISCED Huíla), Brian Huntley (South Africa), John Hilton and Rainer Von Brandis (Wild Bird Trust) for logistical and administrative support. 


\section{Appendix 1}

Checklist of the amphibians recorded in Angola, based on historical records and on confirmed records from recent surveys. Taxonomy follows Frost (2018). Unconfirmed records are not included. To avoid redundancy, records included in existing compilations (e.g. Monard 1937; Ruas 1996) are mentioned under the compilation reference, and the original reference(s) is not included in the list

\begin{tabular}{|c|c|c|}
\hline Common name & Species & References \\
\hline \multicolumn{3}{|c|}{ Family Arthroleptidae } \\
\hline $\begin{array}{l}\text { Carqueja's } \\
\text { Squeaker }\end{array}$ & $\begin{array}{l}\text { Arthroleptis carquejai } \\
\text { (Ferreira, 1906) }\end{array}$ & Ferreira (1906) \\
\hline $\begin{array}{l}\text { Lameer's } \\
\text { Squeaker }\end{array}$ & $\begin{array}{l}\text { Arthroleptis lameerei (De } \\
\text { Witte, 1921) }\end{array}$ & Laurent (1964) and Ruas (1996) \\
\hline $\begin{array}{l}\text { Tanganyika } \\
\text { Screeching Frog }\end{array}$ & $\begin{array}{l}\text { Arthroleptis spinalis } \\
\text { (Boulenger, 1919) }\end{array}$ & Laurent (1950) \\
\hline $\begin{array}{l}\text { Common } \\
\text { Squeaker }\end{array}$ & $\begin{array}{l}\text { Arthroleptis stenodactylus } \\
\text { (Pfeffer, 1893) }\end{array}$ & $\begin{array}{l}\text { Laurent (1964), Ruas (1996) and Conradie et } \\
\text { al. (unpub. data) }\end{array}$ \\
\hline $\begin{array}{l}\text { Variable } \\
\text { Squeaker }\end{array}$ & $\begin{array}{l}\text { Arthroleptis variabilis } \\
\text { (Matschie, 1893) }\end{array}$ & Baptista and Vaz Pinto (unpub. data) \\
\hline Plain Squeaker & $\begin{array}{l}\text { Arthroleptis xenochirus } \\
\text { (Boulenger, 1905) }\end{array}$ & $\begin{array}{l}\text { Monard (1937), Laurent (1964), Ruas } \\
\text { (1996), Ceríaco et al. (2018b), Conradie et } \\
\text { al. (unpub. data), Baptista and Vaz Pinto } \\
\text { (unpub. data), and Ernst (unpub. data) }\end{array}$ \\
\hline $\begin{array}{l}\text { Anchieta's } \\
\text { Treefrog }\end{array}$ & $\begin{array}{l}\text { Leptopelis anchietae } \\
\text { (Bocage, 1873) }\end{array}$ & $\begin{array}{l}\text { Bocage (1895), Boulenger (1905), Schmidt } \\
\text { (1936), Monard (1937), Laurent (1964), } \\
\text { Conradie et al. (2016), Baptista et al. (2018), } \\
\text { (in prep.) and Ernst (unpub. data) }\end{array}$ \\
\hline $\begin{array}{l}\text { Gaboon Forest } \\
\text { Treefrog }\end{array}$ & $\begin{array}{l}\text { Leptopelis aubryi (Duméril, } \\
1856 \text { ) }\end{array}$ & Peters (1887) and Laurent (1954) \\
\hline $\begin{array}{l}\text { Bocage's } \\
\text { Burrowing } \\
\text { Treefrog }\end{array}$ & $\begin{array}{l}\text { Leptopelis bocagii (Günther, } \\
1865 \text { ) }\end{array}$ & $\begin{array}{l}\text { Bocage (1895), Monard (1937), Hellmich } \\
\text { (1957b), Laurent (1954, 1964), Ceríaco et al. } \\
\text { (2018b), Baptista et al (2018, in prep), } \\
\text { Baptista and Vaz Pinto (unpub. data) and } \\
\text { Conradie et al. (unpub. data) }\end{array}$ \\
\hline $\begin{array}{l}\text { Efulen Forest } \\
\text { Treefrog }\end{array}$ & $\begin{array}{l}\text { Leptopelis calcaratus } \\
\text { (Boulenger, 1906) }\end{array}$ & Baptista and Vaz Pinto (unpub. data) \\
\hline $\begin{array}{l}\text { Cinnamon } \\
\text { Treefrog }\end{array}$ & $\begin{array}{l}\text { Leptopelis cynnamomeus } \\
\text { (Bocage, 1893) }\end{array}$ & $\begin{array}{l}\text { Bocage (1895), Monard (1937) and Laurent } \\
\text { (1964) }\end{array}$ \\
\hline $\begin{array}{l}\text { Congulo Forest } \\
\text { Treefrog }\end{array}$ & $\begin{array}{l}\text { Leptopelis jordani (Parker, } \\
\text { 1936) }\end{array}$ & Parker (1936) and Baptista et al. (2017) \\
\hline $\begin{array}{l}\text { Quissange Forest } \\
\text { Treefrog }\end{array}$ & $\begin{array}{l}\text { Leptopelis marginatus } \\
\text { (Bocage, 1895) }\end{array}$ & Bocage (1895) \\
\hline $\begin{array}{l}\text { Kanole Forest } \\
\text { Treefrog }\end{array}$ & $\begin{array}{l}\text { Leptopelis cf. parvus } \\
\text { (Schmidt and Inger, 1959) }\end{array}$ & Conradie et al. (unpub. data) \\
\hline $\begin{array}{l}\text { Rusty Forest } \\
\text { Treefrog }\end{array}$ & $\begin{array}{l}\text { Leptopelis viridis (Günther, } \\
\text { 1869) }\end{array}$ & Boulenger (1882) and Bocage (1895) \\
\hline Hairy Frog & $\begin{array}{l}\text { Trichobatrachus robustus } \\
\text { (Boulenger, 1900) }\end{array}$ & Ernst et al. (2014) \\
\hline
\end{tabular}




\begin{tabular}{|c|c|c|}
\hline Common name & Species & References \\
\hline \multicolumn{3}{|c|}{ Family Brevicipitidae } \\
\hline $\begin{array}{l}\text { Common Rain } \\
\text { Frog }\end{array}$ & $\begin{array}{l}\text { Breviceps cf. adspersus } \\
\text { (Peters, 1882) }\end{array}$ & $\begin{array}{l}\text { Bocage (1895), Monard (1937), Hellmich } \\
\text { (1957b), Laurent (1964), Ruas (1996) and } \\
\text { Conradie et al. (unpub. data) }\end{array}$ \\
\hline \multicolumn{3}{|l|}{ Family Bufonidae } \\
\hline $\begin{array}{l}\text { Dark-sided Forest } \\
\text { Toad }\end{array}$ & $\begin{array}{l}\text { Mertensophryne } \\
\text { melanopleura (Schmidt and } \\
\text { Inger, 1959) }\end{array}$ & Ruas (1996) \\
\hline $\begin{array}{l}\text { Mocquard's } \\
\text { Forest Toad }\end{array}$ & $\begin{array}{l}\text { Mertensophryne mocquardi } \\
\text { (Angel, 1924) }\end{array}$ & Monard (1937) \\
\hline $\begin{array}{l}\text { Dombe Pygmy } \\
\text { Toad }\end{array}$ & $\begin{array}{l}\text { Poyntonophrynus dombensis } \\
\text { (Bocage, 1895) }\end{array}$ & $\begin{array}{l}\text { Bocage (1895), Poynton and Haake (1993), } \\
\text { Ceríaco et al. (2018a) and Vaz Pinto and } \\
\text { Branch (unpub. data) }\end{array}$ \\
\hline $\begin{array}{l}\text { Grandison's } \\
\text { Pygmy Toad }\end{array}$ & $\begin{array}{l}\text { Poyntonophrynus } \\
\text { grandisonae (Poynton and } \\
\text { Haacke, 1993) }\end{array}$ & $\begin{array}{l}\text { Poynton and Haacke (1993) and Ceríaco et } \\
\text { al. (2018a) }\end{array}$ \\
\hline $\begin{array}{l}\text { Kavango Pygmy } \\
\text { Toad Toad }\end{array}$ & $\begin{array}{l}\text { Poyntonophrynus } \\
\text { kavangensis (Poynton and } \\
\text { Broadley, 1988) }\end{array}$ & $\begin{array}{l}\text { Poynton and Haacke (1993), Ruas (1996) } \\
\text { and Vaz Pinto (unpub. data) }\end{array}$ \\
\hline $\begin{array}{l}\text { Serra da Neve } \\
\text { Pygmy Toad }\end{array}$ & $\begin{array}{l}\text { Poyntonophrynus pachnodes } \\
\text { (Ceríaco et al. in press.) }\end{array}$ & Ceríaco et al. (2018a) \\
\hline Red Toad & $\begin{array}{l}\text { Schismaderma carens (Smith, } \\
1848 \text { ) }\end{array}$ & $\begin{array}{l}\text { Monard (1937), Ruas (1996) and Baptista } \\
\text { and Vaz Pinto (unpub. data) }\end{array}$ \\
\hline Buchner's Toad & $\begin{array}{l}\text { Sclerophrys buchneri (Peters, } \\
\text { 1882) }\end{array}$ & Peters $(1882)$ \\
\hline Somber Toad & $\begin{array}{l}\text { Sclerophrys funerea (Bocage, } \\
1866 \text { ) }\end{array}$ & $\begin{array}{l}\text { Bocage (1895), Monard (1937), Laurent } \\
(1954,1964) \text {, Ruas (1996) and Conradie et } \\
\text { al. (2016) }\end{array}$ \\
\hline Guttural Toad & $\begin{array}{l}\text { Sclerophrys gutturalis } \\
\text { (Power, 1927) }\end{array}$ & $\begin{array}{l}\text { Ruas (1996, 2002), Conradie et al. (2016, } \\
\text { unpub. data), Baptista et al. (2018), Baptista } \\
\text { and Vaz Pinto (unpub. data) }\end{array}$ \\
\hline Lemaire's Toad & $\begin{array}{l}\text { Sclerophrys lemairii } \\
\text { (Boulenger, 1901) }\end{array}$ & $\begin{array}{l}\text { Laurent (1950, 1964), Ruas (1996) and } \\
\text { Conradie et al. (2016) }\end{array}$ \\
\hline $\begin{array}{l}\text { Western Olive } \\
\text { Toad }\end{array}$ & $\begin{array}{l}\text { Sclerophrys poweri (Hewitt, } \\
\text { 1935) }\end{array}$ & $\begin{array}{l}\text { Conradie et al. (2016) and Baptista et al. (in } \\
\text { press) }\end{array}$ \\
\hline $\begin{array}{l}\text { Merten's Striped } \\
\text { Toad }\end{array}$ & $\begin{array}{l}\text { Sclerophrys pusilla (Mertens, } \\
\text { 1937) }\end{array}$ & $\begin{array}{l}\text { Ruas (1996, 2002), Conradie et al. (2016), } \\
\text { Poynton et al. (2016), Ceríaco et al. (2018b), } \\
\text { Baptista et al. (2018) and Baptista and Vaz } \\
\text { Pinto (unpub. data) }\end{array}$ \\
\hline Common Toad & $\begin{array}{l}\text { Sclerophrys regularis (Reuss, } \\
1833 \text { ) }\end{array}$ & $\begin{array}{l}\text { Bocage (1895), Monard (1937), Laurent } \\
\text { (1964), Ruas (1996), Ceríaco et al. (2014b) } \\
\text { and Vaz Pinto and Baptista (unpub. data) }\end{array}$ \\
\hline \multicolumn{3}{|c|}{ Family Dicroglossidae } \\
\hline $\begin{array}{l}\text { Crowned } \\
\text { Bullfrog }\end{array}$ & $\begin{array}{l}\text { Hoplobatrachus occipitalis } \\
\text { (Günther, 1858) }\end{array}$ & $\begin{array}{l}\text { Bocage (1895), Monard (1937), Hellmich } \\
\text { (1957b) and Ruas (1996), Baptista (unpub. } \\
\text { data) }\end{array}$ \\
\hline
\end{tabular}




\begin{tabular}{|c|c|c|}
\hline Common name & Species & References \\
\hline \multicolumn{3}{|c|}{ Family Hemisotidae } \\
\hline $\begin{array}{l}\text { Guinea } \\
\text { Snout-burrower }\end{array}$ & $\begin{array}{l}\text { Hemisus guineensis (Cope, } \\
1865)\end{array}$ & $\begin{array}{l}\text { Laurent (1964), Ceríaco et al. (2018b), } \\
\text { Conradie et al. (unpub. data) and Baptista } \\
\text { and Vaz Pinto (unpub. data) }\end{array}$ \\
\hline $\begin{array}{l}\text { Marbled } \\
\text { Snout-burrower }\end{array}$ & $\begin{array}{l}\text { Hemisus marmoratus (Peters, } \\
\text { 1854) }\end{array}$ & $\begin{array}{l}\text { Bocage (1895), Monard (1937), Hellmich } \\
\text { (1957b), Ruas (1996) and Baptista et al. (in } \\
\text { prep.) }\end{array}$ \\
\hline \multicolumn{3}{|c|}{ Family Hyperoliidae } \\
\hline $\begin{array}{l}\text { Striped Spiny } \\
\text { Reed Frog }\end{array}$ & $\begin{array}{l}\text { Afrixalus dorsalis (Peters, } \\
\text { 1875) }\end{array}$ & $\begin{array}{l}\text { Laurent (1964) and Baptista and Vaz Pinto } \\
\text { (unpub. data) }\end{array}$ \\
\hline $\begin{array}{l}\text { Four Lined Reed } \\
\text { Frog }\end{array}$ & $\begin{array}{l}\text { Afrixalus fulvovittatus (Cope, } \\
\text { 1861) }\end{array}$ & Bocage (1866a) and Ferreira (1904) \\
\hline $\begin{array}{l}\text { Osorio’s Spiny } \\
\text { Reed Frog }\end{array}$ & $\begin{array}{l}\text { Afrixalus osorioi (Ferreira, } \\
\text { 1906) }\end{array}$ & $\begin{array}{l}\text { Ferreira (1906), Baptista and Vaz Pinto } \\
\text { (unpub. data) and Ernst (unpub. data) }\end{array}$ \\
\hline $\begin{array}{l}\text { Four-Lined Spiny } \\
\text { Reed Frog }\end{array}$ & $\begin{array}{l}\text { Afrixalus quadrivittatus } \\
\text { (Werner, 1908) }\end{array}$ & Peters (1887) and Perret (1976) \\
\hline $\begin{array}{l}\text { De Witte's Spiny } \\
\text { Reed Frog }\end{array}$ & $\begin{array}{l}\text { Afrixalus wittei (Laurent, } \\
\text { 1941) }\end{array}$ & $\begin{array}{l}\text { Ceríaco et al. (2018b), Baptista and Vaz } \\
\text { Pinto (unpub. data) and Ernst (unpub. data) }\end{array}$ \\
\hline $\begin{array}{l}\text { Sprinkled Long } \\
\text { Reed Frog }\end{array}$ & $\begin{array}{l}\text { Hyperolius adspersus (Peters, } \\
\text { 1877) }\end{array}$ & Laurent (1964) \\
\hline $\begin{array}{l}\text { Benguela Long } \\
\text { Reed Frog }\end{array}$ & $\begin{array}{l}\text { Hyperolius benguellensis } \\
\text { (Bocage, 1893) }\end{array}$ & $\begin{array}{l}\text { Bocage (1895), Ferreira (1906), Monard } \\
\text { (1937), Laurent (1950), Channing et al. } \\
\text { (2013), Conradie et al. (2016) and Baptista et } \\
\text { al. (2018) }\end{array}$ \\
\hline $\begin{array}{l}\text { Two-colored } \\
\text { Reed Frog }\end{array}$ & $\begin{array}{l}\text { Hyperolius bicolor (Ahl, } \\
\text { 1931) }\end{array}$ & Ahl (1931) \\
\hline $\begin{array}{l}\text { Bocage's Reed } \\
\text { Frog }\end{array}$ & $\begin{array}{l}\text { Hyperolius bocagei } \\
\text { (Steindachner, 1867) }\end{array}$ & $\begin{array}{l}\text { Monard (1937), Laurent (1950, 1954, 1964), } \\
\text { Ceríaco et al. (2014b), Conradie (unpub. } \\
\text { data), Baptista and Vaz Pinto (unpub. data) } \\
\text { and Ernst (unpub. data) }\end{array}$ \\
\hline $\begin{array}{l}\text { Chela Mountain } \\
\text { Reed Frog }\end{array}$ & $\begin{array}{l}\text { Hyperolius chelaensis } \\
\text { (Conradie et al. 2012) }\end{array}$ & Conradie et al. (2012) \\
\hline $\begin{array}{l}\text { Monard's Reed } \\
\text { Frog }\end{array}$ & $\begin{array}{l}\text { Hyperolius cinereus } \\
\text { (Monard, 1937) }\end{array}$ & $\begin{array}{l}\text { Monard (1937), Conradie et al. (2016), } \\
\text { Baptista et al. (2018), Baptista and Vaz Pinto } \\
\text { (unpub. data) and Conradie et al. (unpub. } \\
\text { data) }\end{array}$ \\
\hline $\begin{array}{l}\text { Dimorphic Reed } \\
\text { Frog }\end{array}$ & $\begin{array}{l}\text { Hyperolius } \\
\text { cinnamomeoventris (Bocage, } \\
1866)\end{array}$ & $\begin{array}{l}\text { Monard (1937), Laurent (1950, 1954, 1964), } \\
\text { Ceríaco et al. (2016c), (2018b) and Baptista } \\
\text { and Vaz Pinto (unpub. data) }\end{array}$ \\
\hline $\begin{array}{l}\text { Variable Reed } \\
\text { Frog }\end{array}$ & $\begin{array}{l}\text { Hyperolius concolor } \\
\text { (Hallowell, 1844) }\end{array}$ & Monard (1937) \\
\hline $\begin{array}{l}\text { Dartevelle's Long } \\
\text { Reed frog }\end{array}$ & $\begin{array}{l}\text { Hyperolius dartevellei } \\
\text { (Laurent, 1943) }\end{array}$ & Laurent (1964) and Channing et al. (2013) \\
\hline $\begin{array}{l}\text { Brown-throated } \\
\text { Reed Frog }\end{array}$ & $\begin{array}{l}\text { Hyperolius fuscigula } \\
\text { (Bocage, 1866) }\end{array}$ & Bocage (1866) \\
\hline \multicolumn{3}{|c|}{ Family Hemisotidae (cont.) } \\
\hline $\begin{array}{l}\text { Loanda Reed } \\
\text { Frog }\end{array}$ & $\begin{array}{l}\text { Hyperolius gularis (Ahl, } \\
\text { 1931) }\end{array}$ & Ahl (1931) \\
\hline Kivu Reed Frog & $\begin{array}{l}\text { Hyperolius kivuensis (Ahl, } \\
\text { 1931) }\end{array}$ & Laurent $(1950,1954)$ \\
\hline
\end{tabular}




\begin{tabular}{|c|c|c|}
\hline Common name & Species & References \\
\hline Lang's Reed Frog & $\begin{array}{l}\text { Hyperolius langi (Noble, } \\
\text { 1924) }\end{array}$ & Monard (1937) \\
\hline $\begin{array}{l}\text { Landana Reed } \\
\text { Frog }\end{array}$ & $\begin{array}{l}\text { Hyperolius lucani } \\
\text { (Rochebrune, 1885) }\end{array}$ & Rochebrune (1885) \\
\hline $\begin{array}{l}\text { Cabinda Reed } \\
\text { Frog }\end{array}$ & $\begin{array}{l}\text { Hyperolius maestus } \\
\text { (Rochebrune, 1885) }\end{array}$ & Rochebrune (1885) \\
\hline $\begin{array}{l}\text { Marbled Reed } \\
\text { Frog }\end{array}$ & $\begin{array}{l}\text { Hyperolius marmoratus } \\
\text { (Rapp, 1842) }\end{array}$ & $\begin{array}{l}\text { Boulenger (1882), Bocage (1895) and } \\
\text { Monard (1937) }\end{array}$ \\
\hline $\begin{array}{l}\text { Large-nosed } \\
\text { Long Reed Frog }\end{array}$ & $\begin{array}{l}\text { Hyperolius nasutus (Günther, } \\
\text { 1865) }\end{array}$ & $\begin{array}{l}\text { Bocage (1895), Monard (1937), Laurent } \\
\text { (1950, 1954, 1964), Hellmich (1957b), } \\
\text { Baptista and Vaz Pinto (unpub. data) and } \\
\text { Ceríaco et al. (2018b) }\end{array}$ \\
\hline $\begin{array}{l}\text { Nobre's Reed } \\
\text { Frog }\end{array}$ & $\begin{array}{l}\text { Hyperolius nobrei (Ferreira, } \\
\text { 1906) }\end{array}$ & Ferreira (1906) \\
\hline $\begin{array}{l}\text { Angolan Reed } \\
\text { Frog }\end{array}$ & $\begin{array}{l}\text { Hyperolius parallelus } \\
\text { (Günther, 1858) }\end{array}$ & $\begin{array}{l}\text { Monard (1937), Laurent (1950, 1954, 1964), } \\
\text { Ceríaco et al. (2018b), Conradie et al. } \\
\text { (unpub. data), Baptista et al. (2018) and } \\
\text { Baptista and Vaz Pinto (unpub. data) }\end{array}$ \\
\hline $\begin{array}{l}\text { Leopard Reed } \\
\text { Frog }\end{array}$ & $\begin{array}{l}\text { Hyperolius pardalis (Laurent, } \\
\text { 1948) }\end{array}$ & Conradie (unpub. data) \\
\hline $\begin{array}{l}\text { Rio Luinha Reed } \\
\text { Frog }\end{array}$ & $\begin{array}{l}\text { Hyperolius platyceps } \\
\text { (Boulenger, 1900) }\end{array}$ & $\begin{array}{l}\text { Monard (1937), Laurent }(1950,1954) \text { and } \\
\text { Baptista and Vaz Pinto (unpub. data) }\end{array}$ \\
\hline $\begin{array}{l}\text { Tshimbulu Reed } \\
\text { Frog }\end{array}$ & $\begin{array}{l}\text { Hyperolius polli (Laurent, } \\
1943 \text { ) }\end{array}$ & Laurent (1954) \\
\hline $\begin{array}{l}\text { Rochebrune's } \\
\text { Reed Frog }\end{array}$ & $\begin{array}{l}\text { Hyperolius protchei } \\
\text { (Rochebrune, 1885) }\end{array}$ & Rochebrune (1885) \\
\hline $\begin{array}{l}\text { Five-striped Reed } \\
\text { Frog }\end{array}$ & $\begin{array}{l}\text { Hyperolius quinquevittatus } \\
\text { (Bocage, 1866) }\end{array}$ & $\begin{array}{l}\text { Bocage (1895), Laurent }(1950,1954) \text { and } \\
\text { Baptista and Vaz Pinto (unpub. data) }\end{array}$ \\
\hline $\begin{array}{l}\text { Raymond's Reed } \\
\text { Frog }\end{array}$ & $\begin{array}{l}\text { Hyperolius raymondi } \\
\text { (Conradie et al. 2013) }\end{array}$ & Conradie et al. (2013) \\
\hline $\begin{array}{l}\text { African Reed } \\
\text { Frog }\end{array}$ & $\begin{array}{l}\text { Hyperolius rhizophilus } \\
\text { (Rochebrune, 1885) }\end{array}$ & Rochebrune (1885) \\
\hline $\begin{array}{l}\text { Steindachner's } \\
\text { Reed Frog }\end{array}$ & $\begin{array}{l}\text { Hyperolius steindachneri } \\
\text { (Bocage, 1866) }\end{array}$ & $\begin{array}{l}\text { Bocage (1895), Monard (1937), Laurent } \\
(1950,1954,1964), \text { Poynton and Haacke } \\
\text { (1993) and Channing and Vaz Pinto (unpub. } \\
\text { data) }\end{array}$ \\
\hline $\begin{array}{l}\text { Luita River Reed } \\
\text { Frog }\end{array}$ & $\begin{array}{l}\text { Hyperolius vilhenai (Laurent, } \\
\text { 1964) }\end{array}$ & Laurent (1964) \\
\hline Kuvangu Kassina & $\begin{array}{l}\text { Kassina kuvangensis } \\
\text { (Monard, 1937) }\end{array}$ & $\begin{array}{l}\text { Monard (1937) and Conradie et al. (2016, } \\
\text { unpub. data) }\end{array}$ \\
\hline \multicolumn{3}{|c|}{ Family Hemisotidae (cont.) } \\
\hline Bubbling Kassina & $\begin{array}{l}\text { Kassina senegalensis } \\
\text { (Duméril and Bibron, 1841) }\end{array}$ & $\begin{array}{l}\text { Monard (1937), Laurent (1954, 1964), } \\
\text { Poynton and Haacke (1993), Conradie et al. } \\
\text { (2016), Baptista et al. (2018), Baptista and } \\
\text { Vaz Pinto (unpub. data), Conradie et al. } \\
\text { (unpub. data) and Ernst (unpub. data) }\end{array}$ \\
\hline $\begin{array}{l}\text { De Witte's } \\
\text { Clicking Frog }\end{array}$ & $\begin{array}{l}\text { Kassinula wittei (Laurent, } \\
\text { 1940) }\end{array}$ & Conradie et. al (unpub. data) \\
\hline
\end{tabular}




\begin{tabular}{|c|c|c|}
\hline Common name & Species & References \\
\hline \multicolumn{3}{|c|}{ Family Microhylidae } \\
\hline $\begin{array}{l}\text { Spotted Rubber } \\
\text { Frog }\end{array}$ & $\begin{array}{l}\text { Phrynomantis affinis } \\
\text { (Boulenger, 1901) }\end{array}$ & Laurent (1964) \\
\hline $\begin{array}{l}\text { Marbled Rubber } \\
\text { Frog }\end{array}$ & $\begin{array}{l}\text { Phrynomantis annectens } \\
\text { (Werner, 1910) }\end{array}$ & $\begin{array}{l}\text { Ruas (1996) and Vaz Pinto and Branch } \\
\text { (unpub. data) }\end{array}$ \\
\hline $\begin{array}{l}\text { Banded Rubber } \\
\text { Frog }\end{array}$ & $\begin{array}{l}\text { Phrynomantis bifasciatus } \\
\text { (Smith, 1847) }\end{array}$ & $\begin{array}{l}\text { Boulenger (1882), Monard (1937), Ruas } \\
\text { (1996), Channing (unpub. data) and Baptista } \\
\text { et al. (unpub. data) }\end{array}$ \\
\hline \multicolumn{3}{|c|}{ Family Phrynobatrachidae } \\
\hline $\begin{array}{l}\text { Ahl's Puddle } \\
\text { Frog }\end{array}$ & $\begin{array}{l}\text { Phrynobatrachus } \\
\text { brevipalmatus (Ahl, 1925) }\end{array}$ & Ahl (1925) \\
\hline $\begin{array}{l}\text { Cryptic Puddle } \\
\text { Frog }\end{array}$ & $\begin{array}{l}\text { Phrynobatrachus cryptotis } \\
\text { (Schmidt and Inger, 1959) }\end{array}$ & Laurent (1964) \\
\hline $\begin{array}{l}\text { Mababe Puddle } \\
\text { Frog }\end{array}$ & $\begin{array}{l}\text { Phrynobatrachus } \\
\text { mababiensis (FitzSimons, } \\
\text { 1932) }\end{array}$ & $\begin{array}{l}\text { Poynton and Haacke (1993), Conradie et al. } \\
\text { (2016, unpub. data) and Baptista and Vaz } \\
\text { Pinto (unpub. data) }\end{array}$ \\
\hline $\begin{array}{l}\text { Snoring Puddle } \\
\text { Frog }\end{array}$ & $\begin{array}{l}\text { Phrynobatrachus natalensis } \\
\text { (Smith, 1849) }\end{array}$ & $\begin{array}{l}\text { Bocage (1895), Monard (1937), Hellmich } \\
\text { (1957b), Ruas (1996), Conradie et al. (2016, } \\
\text { unpub. data), Ceríaco et al. (2018b), Baptista } \\
\text { et al. (2018, in press) and Baptista and Vaz } \\
\text { Pinto (unpub. data) }\end{array}$ \\
\hline $\begin{array}{l}\text { Loanda River } \\
\text { Frog }\end{array}$ & $\begin{array}{l}\text { Phrynobatrachus parvulus } \\
\text { (Boulenger, 1905) }\end{array}$ & $\begin{array}{l}\text { Ruas (1996), Baptista and Vaz Pinto (unpub. } \\
\text { data) and Conradie et al. (unpub. data) }\end{array}$ \\
\hline \multicolumn{3}{|l|}{ Family Pipidae } \\
\hline $\begin{array}{l}\text { Andre's Clawed } \\
\text { Frog }\end{array}$ & $\begin{array}{l}\text { Xenopus andrei (Loumont, } \\
\text { 1983) }\end{array}$ & Ernst et al. (2015) \\
\hline $\begin{array}{l}\text { Southern Tropical } \\
\text { Clawed Frog }\end{array}$ & $\begin{array}{l}\text { Xenopus epitropicalis } \\
\text { (Fischberg et al., 1982) }\end{array}$ & $\begin{array}{l}\text { Laurent }(1950,1954) \text { and Klein (unpub. } \\
\text { data) }\end{array}$ \\
\hline $\begin{array}{l}\text { Müller's Clawed } \\
\text { Frog }\end{array}$ & $\begin{array}{l}\text { Xenopus muelleri (Peters, } \\
\text { 1844) }\end{array}$ & Conradie et al. (2016) \\
\hline $\begin{array}{l}\text { Peters' Clawed } \\
\text { Frog }\end{array}$ & $\begin{array}{l}\text { Xenopus petersii (Bocage, } \\
1895)\end{array}$ & $\begin{array}{l}\text { Bocage (1895), Monard (1937), Hellmich } \\
\text { (1957b), Ruas (1996), Baptista et al. (2018), } \\
\text { Baptista and Vaz Pinto (unpub. data), Ceríaco } \\
\text { et al. (2018b) and Ernst (unpub. data) }\end{array}$ \\
\hline $\begin{array}{l}\text { Power's Clawed } \\
\text { Frog }\end{array}$ & $\begin{array}{l}\text { Xenopus poweri (Hewitt, } \\
\text { 1927) }\end{array}$ & Conradie et al. (2016) \\
\hline
\end{tabular}

\section{Family Pipidae (cont.)}

\begin{tabular}{l|l|l}
\hline $\begin{array}{l}\text { Clawed Frog } \\
\text { Family Ptychadenidae }\end{array}$ & Laurent (1950) \\
\hline $\begin{array}{l}\text { Common Ornate } \\
\text { Frog }\end{array}$ & $\begin{array}{l}\text { Hildebrandtia ornata (Peters, } \\
\text { 1878) }\end{array}$ & Poynton and Haacke (1993) \\
\hline $\begin{array}{l}\text { Angola Ornate } \\
\text { Frog }\end{array}$ & $\begin{array}{l}\text { Hildebrandtia ornatissima } \\
\text { (Bocage, 1879) }\end{array}$ & $\begin{array}{l}\text { Bocage (1895), Monard (1937) and Baptista } \\
\text { and Vaz Pinto (unpub. data) }\end{array}$ \\
\hline $\begin{array}{l}\text { Anchieta's Grass } \\
\text { Frog }\end{array}$ & $\begin{array}{l}\text { Ptychadena anchietae } \\
\text { (Bocage, 1868) }\end{array}$ & $\begin{array}{l}\text { Ruas (1996), Ceríaco et al. (In press.), } \\
\text { Baptista et al (2018) and Baptista and Vaz } \\
\text { Pinto (unpub. data) }\end{array}$ \\
\hline $\begin{array}{l}\text { Ansorge's Grass } \\
\text { Frog }\end{array}$ & $\begin{array}{l}\text { Ptychadena ansorgii } \\
\text { (Boulenger, 1905) }\end{array}$ & Monard (1937) and Ruas (1996) \\
\hline
\end{tabular}




\begin{tabular}{|c|c|c|}
\hline Common name & Species & References \\
\hline $\begin{array}{l}\text { Rough Grass } \\
\text { Frog }\end{array}$ & $\begin{array}{l}\text { Ptychadena bunoderma } \\
\text { (Boulenger, 1907) }\end{array}$ & $\begin{array}{l}\text { Monard (1937), Ruas (1996) and Conradie et } \\
\text { al. (unpub. data) }\end{array}$ \\
\hline $\begin{array}{l}\text { Grandison's } \\
\text { Grass Frog }\end{array}$ & $\begin{array}{l}\text { Ptychadena grandisonae } \\
\text { (Laurent, 1954) }\end{array}$ & Ruas (1996) \\
\hline $\begin{array}{l}\text { Guibe's Grass } \\
\text { Frog }\end{array}$ & $\begin{array}{l}\text { Ptychadena guibei (Laurent, } \\
\text { 1954) }\end{array}$ & $\begin{array}{l}\text { Ruas (1996), Ceríaco et al. (in press), } \\
\text { Conradie et al. (2016) and Baptista and Vaz } \\
\text { Pinto (unpub. data) }\end{array}$ \\
\hline $\begin{array}{l}\text { Keiling's Grass } \\
\text { Frog }\end{array}$ & $\begin{array}{l}\text { Ptychadena keilingi (Monard, } \\
\text { 1937) }\end{array}$ & $\begin{array}{l}\text { Ruas (1996) and Conradie et al. (unpub. } \\
\text { data) }\end{array}$ \\
\hline $\begin{array}{l}\text { Mozambique } \\
\text { Grass Frog }\end{array}$ & $\begin{array}{l}\text { Ptychadena cf. mossambica } \\
\text { (Peters, 1854) }\end{array}$ & $\begin{array}{l}\text { Conradie et al. (2016) and Conradie (unpub. } \\
\text { data) }\end{array}$ \\
\hline Nile Grass Frog & $\begin{array}{l}\text { Ptychadena nilotica (Seetzen, } \\
\text { 1855) }\end{array}$ & $\begin{array}{l}\text { Monard (1937), Schmidt and Inger (1959), } \\
\text { Ruas (1996), Conradie et al. (2016), Dehling } \\
\text { and Sinsch (2013b) and Zimkus et al. (2017) }\end{array}$ \\
\hline $\begin{array}{l}\text { Sharp-nosed } \\
\text { Grass Frog }\end{array}$ & $\begin{array}{l}\text { Ptychadena oxyrhynchus } \\
\text { (Smith, 1849) }\end{array}$ & $\begin{array}{l}\text { Monard (1937), Hellmich (1957b), Ruas } \\
\text { (1996), Ceríaco et al. (2018b), Conradie et } \\
\text { al. (2016) and Baptista (unpub. data) }\end{array}$ \\
\hline Many-Grass Frog & $\begin{array}{l}\text { Ptychadena perplicata } \\
\text { (Laurent, 1964) }\end{array}$ & Laurent (1964) \\
\hline $\begin{array}{l}\text { Striped Grass } \\
\text { Frog }\end{array}$ & $\begin{array}{l}\text { Ptychadena porosissima } \\
\text { (Steindachner, 1867) }\end{array}$ & $\begin{array}{l}\text { Ruas (1996), Conradie et al. (unpub. data) } \\
\text { and Channing et al. (2012) }\end{array}$ \\
\hline $\begin{array}{l}\text { Spot-bellied } \\
\text { Grass Frog }\end{array}$ & $\begin{array}{l}\text { Ptychadena subpunctata } \\
\text { (Bocage, 1866) }\end{array}$ & $\begin{array}{l}\text { Ruas (1996), Conradie et al. (2016) and } \\
\text { Baptista (unpub. data) }\end{array}$ \\
\hline Small Grass Frog & $\begin{array}{l}\text { Ptychadena taenioscelis } \\
\text { (Laurent, 1954) }\end{array}$ & Ruas (1996) and Conradie et al. (2016) \\
\hline $\begin{array}{l}\text { Upemba Grass } \\
\text { Frog }\end{array}$ & $\begin{array}{l}\text { Ptychadena upembae } \\
\text { (Schmidt and Inger, 1959) }\end{array}$ & Ruas (1996) \\
\hline $\begin{array}{l}\text { Udzungwa Grass } \\
\text { Frog }\end{array}$ & $\begin{array}{l}\text { Ptychadena uzungwensis } \\
\text { (Loveridge, 1932) }\end{array}$ & $\begin{array}{l}\text { Ruas (1996) and Conradie et al. (2016, } \\
\text { unpub. data) }\end{array}$ \\
\hline \multicolumn{3}{|c|}{ Family Pyxicephalidae } \\
\hline $\begin{array}{l}\text { Angola River } \\
\text { Frog }\end{array}$ & $\begin{array}{l}\text { Amietia angolensis (Bocage, } \\
1866)\end{array}$ & $\begin{array}{l}\text { Bocage (1895), Monard (1937), Ruas (1996), } \\
\text { Channing and Baptista (2013), Ceríaco et al. } \\
\text { (2016b), Channing et al. (2016), Baptista et } \\
\text { al. (2018) and Baptista and Vaz Pinto (unpub. } \\
\text { data) }\end{array}$ \\
\hline African Bullfrog & $\begin{array}{l}\text { Pyxicephalus adspersus } \\
\text { (Tschudi, 1838) }\end{array}$ & Monard (1937) and Ruas (1996) \\
\hline $\begin{array}{l}\text { Cryptic Sand } \\
\text { Frog }\end{array}$ & $\begin{array}{l}\text { Tomopterna cryptotis } \\
\text { (Boulenger, 1907) }\end{array}$ & $\begin{array}{l}\text { Monard (1937), Ruas (1996), Conradie et al. } \\
\text { (2016) and Baptista et al. (in press) }\end{array}$ \\
\hline $\begin{array}{l}\text { Damaraland Sand } \\
\text { Frog }\end{array}$ & $\begin{array}{l}\text { Tomopterna damarensis } \\
\text { (Dawood and Channing, } \\
\text { 2002) }\end{array}$ & $\begin{array}{l}\text { Ceríaco et al. (2016a) and Heinicke et al. } \\
(2017)\end{array}$ \\
\hline Rough Sand Frog & $\begin{array}{l}\text { Tomopterna tuberculosa } \\
\text { (Boulenger, 1882) }\end{array}$ & $\begin{array}{l}\text { Bocage (1895), Monard (1937), Ruas (1996), } \\
\text { Baptista et al (2018, unpub. data) and } \\
\text { Conradie et al. (unpub. data) }\end{array}$ \\
\hline \multicolumn{3}{|l|}{ Family Ranidae } \\
\hline $\begin{array}{l}\text { Forest White- } \\
\text { lipped Frog }\end{array}$ & $\begin{array}{l}\text { Amnirana albolabris } \\
\text { (Hallowell, 1856) }\end{array}$ & $\begin{array}{l}\text { Bocage (1895), Monard (1937), Ruas (1996) } \\
\text { and Jongsma et al. (2018) }\end{array}$ \\
\hline
\end{tabular}




\begin{tabular}{l|l|l}
\hline Common name & Species & References \\
\hline $\begin{array}{l}\text { Darling's } \\
\text { White-lipped } \\
\text { Frog }\end{array}$ & $\begin{array}{l}\text { Amnirana darlingi } \\
\text { (Boulenger, 1902) }\end{array}$ & $\begin{array}{l}\text { Monard (1937), Laurent (1964), Ruas } \\
\text { (1996), Ceríaco et al. (2018b) } \\
\text { Branch and Conradie (2015) and Conradie et } \\
\text { al. (unpub. data) }\end{array}$ \\
\hline $\begin{array}{l}\text { Lemaire's } \\
\text { White-lipped } \\
\text { Frog }\end{array}$ & $\begin{array}{l}\text { Amnirana lemairei (De Witte, } \\
\text { 1921) }\end{array}$ & $\begin{array}{l}\text { Laurent (1964), Ruas (1996) and Baptista } \\
\text { and Vaz Pinto (unpub. data) }\end{array}$ \\
\hline $\begin{array}{l}\text { Andersson's } \\
\text { White-lipped } \\
\text { Frog }\end{array}$ & $\begin{array}{l}\text { Amnirana cf. lepus } \\
\text { (Andersson, 1903) }\end{array}$ & Branch and Conradie (2015) \\
\hline $\begin{array}{l}\text { Parker's } \\
\text { White-lipped } \\
\text { Frog }\end{array}$ & $\begin{array}{l}\text { Amnirana parkeriana } \\
\text { (Mertens, 1938) }\end{array}$ & Mertens (1938) \\
\hline
\end{tabular}

\section{References}

Ahl E (1925 “1923”) Ueber neue afrikanische Frösche der Familie Ranidae. Sitzungsberichte der Gesellschaft Naturforschender Freunde zu Berlin 1923:96-106

Ahl E (1931) Amphibia, Anura III, Polypedatidae. Das Tierreich 55: xvi + 477

Amiet JL (2012) Les Rainettes du Cameroun (Amphibiens Anoures). La Nef des Livres, SaintNazaire, $591 \mathrm{pp}$

Baptista N, António T, Branch WR The herpetofauna of Bicuar National Park and surrounds, southwestern Angola: a first description and preliminary checklist. Amphibian \& Reptile Conservation. (in press).

Baptista N, Vaz Pinto P, Ernst R et al (2017) Cryptic diversity in treefrogs (Leptopelis) of the Angolan escarpment - fitting the pieces together. 13th conference of the Herpetological Association of Africa, Bonamanzi, South Africa

Baptista N, António T, Branch WR (2018) Amphibians and reptiles of the Tundavala region of the Angolan Escarpment. In: Revermann R, Krewenka KM, Schmiedel U et al (eds) Climate change and adaptive land management in Southern Africa - assessments, changes, challenges, and solutions, Biodiversity \& ecology, vol 6, pp 397-403

Beard KH, Vogt KA, Kulmatiski A (2002) Top-down effects of a terrestrial frog on forest nutrient dynamics. Oecologia 133(4):583-593

Beebee TJ, Griffiths RA (2005) The amphibian decline crisis: a watershed for conservation biology? Biol Conserv 125(3):271-285

Blanc CP, Frétey T (2000) Biogeographie des Amphibiens d'Afrique Centrale et d'Angola. Biogeographica 76(3):107-118

Bocage JVB (1866a) Lista dos reptis das possessões portuguesas d' Africa occidental que existem no Museu de Lisboa. Jornal de Sciências Mathemáticas, Physicas e Naturaes. Lisboa 1:37-56

Bocage JVB (1866b) Reptiles nouveaux ou peu connus recueillis dans les possessions portugaises de l'Afrique occidentale, qui se trouvent au Muséum de Lisbonne. Jornal de Sciencias Mathematicas, Physicas e Naturaes. Lisboa I(1):57-78

Bocage JVB (1867) Batraciens nouveaux de I'Afrique occidentale (Loanda et Benguella). Proc Zool Soc London 35:843-846

Bocage JVB (1873) Mélanges erpétologiques. Sur quelques Reptiles et Batraciens nouveux, rares ou peu connues de I'Afrique occidentale. Jornal de Sciências Mathemáticas, Physicas e Naturaes. Lisboa 4(1):209-227

Bocage JVB (1879a) Reptiles et batraciens nouveaux d’ Angola. Jornal de Sciências Mathemáticas, Physicas e Naturaes. Lisboa 7(26):97-99 
Bocage JVB (1879b) Subsidio para a fauna das possessões portuguezas d'África occidental. Jornal de Sciências Mathemáticas, Physicas e Naturaes. Lisboa (1) 7:85-95

Bocage JVB (1882) Reptiles rares ou nouveaux d'Angola. Jornal de Sciencias, Mathemáticas, Physicas e Naturaes. Lisboa (1) 8:299-304

Bocage JVB (1893) Diagnose de quelques nouvelles espéces de reptiles et batraciens d' Angola. Jornal de Sciências Mathemáticas, Physicas e Naturaes. Lisboa (2) 10:115-121

Bocage JVB (1895a) Herpétologie d'Angola et du Congo. Lisbonne, Imprimerie Nationale, 203 $\mathrm{pp}, 19 \mathrm{pls}$

Bocage JVB (1895b) Sur une espêce de Crapaud à ajouter à la faune herpétologique d'Angola. Jornal de Sciências Mathemáticas, Physicas e Naturaes. Lisboa (2) 4:51-53

Bocage JVB (1896a) Mamíferos, aves e réptis da Hanha, no sertão de Benguella. Jornal de Sciências Mathemáticas, Physicas e Naturaes. Lisboa (2) 14:105-114

Bocage JVB (1896b) Répteis de algumas possessões portuguesas de Africa que existem no Museu de Lisboa. Jornal de Sciências Mathemáticas, Physicas e Naturaes 2:65-104

Bocage JVB (1897a) Mamíferos, aves e reptis da Hanha, no sertão de Benguella. Segunda lista. Jornal de Sciências Mathemáticas, Physicas e Naturaes. Lisboa (2):207-211

Bocage JVB (1897b) Mamíferos, réptis e batrachios d'África de que existem exemplares típicos no Museu de Lisboa. Jornal de Sciências Mathemáticas, Physicas e Naturaes. Lisboa (2) 4:187-206

Boulenger GA (1882) Catalogue of the Batrachia Salientia s. Ecaudata in the collection of the British museum, 2nd edn. Taylor and Francis, London

Boulenger GA (1905) A list of the batrachians and reptiles collected by Dr. W. J. Ansorge in Angola, with descriptions of new species. Ann Mag Nat Hist Ser 7 16(92):8-115

Boulenger GA (1907a) Descriptions of three new lizards and a new frog, discovered by Dr. W J. Ansorge in Angola. Ann Mag Nat Hist Ser 7 19:212-214

Boulenger GA (1907b) Description of a new frog discovered by Dr. W. J. Ansorge in Mossamedes, Angola. Ann Mag Nat Hist Ser 7 20:109

Boulenger GA (1919) On Rana ornatissima, Bocage, and R. ruddi, Blgr. Trans Royal Soc S Afr 8:33-37

Branch WR, Bauer AM (2005) The life and herpetological contributions of Andrew Smith. pp. 1-19 in Smith, A. The Herpetological Contributions of Sir Andrew Smith. Society for the Study of Amphibians and Reptiles, Villanova, PA. iv +84 pp

Branch WR, Conradie WC (2015) Herpetofauna da região da Lagoa Carumbo (Herpetofauna of the Carumba Lagoon Area). In: Huntley BJ (ed), Relatório sobre a Expedição Avaliação rápida da Biodiversidade de região da Lagoa Carumbo, Lunda-Norte - Angola, República de Angola. Ministério do Ambiente, pp 194-209, 219p

Branch WR, Baptista N, Keates CW, et al (2019) Rediscovery, taxonomic status, and phylogenetic relationships of two rare and endemic snakes (Serpentes: Psammophinae) from the Angolan Escarpment. Zootaxa, in press

Brito D (2010) Overcoming the Linnean shortfall: data deficiency and biological survey priorities. Basic Appl Ecol 11(8):709-713

Broadley DG (1971) The reptiles and amphibians of Zambia. The Puku, Occ Pap Dept Game Fish Zambia 7:1-143

Brooks C (2012) Biodiversity survey of the upper Angolan Catchment of the Cubango-Okavango River Basin. USAid-Southern Africa. $151 \mathrm{pp}$

Brooks C (2013) Trip report: aquatic biodiversity survey of the lower Cuito and Cuando river systems in Angola. USAid-Southern Africa. 43 pp

Cei JM (1977) Chaves para uma identificação preliminar dos batráquios anuros da R. P. de Angola. Boletim da Sociedade Portuguesa de Ciências Naturais 17:5-26

Ceríaco LMP, Bauer AM, Blackburn et al (2014a) The herpetofauna of the Capanda Dam region, Malanje, Angola. Herpetol Rev 45(4):667-674

Ceríaco LMP, Blackburn DC, Marques MP et al (2014b) Catalogue of the amphibian and reptile type specimens of the Museu de História Natural da Universidade do Porto in Portugal, with some comments on problematic taxa. Alytes 31(1):13-36 
Ceríaco LMP, Bauer AM, Heinicke MP et al (2016a) Geographical distributions: Ptychadenidae, Ptychadena mapacha Channing, 1993 - Mapacha ridged frog in Namibia. Afr Herp News 63:19-20

Ceríaco LMP, de Sá SAC, Bandeira SA et al (2016b) Herpetological survey of Iona National Park and Namibe regional natural park, with a synoptic list of the amphibians and reptiles of Namibe Province, Southwestern Angola. Proc Calif Acad Sci 63(2):15-61

Ceríaco LMP, Marques MP, Bandeira SA et al (2016c) Anfíbios e répteis do Parque Nacional da Cangandala. Instituto Nacional da Biodiversidade e Áreas de Conservação \& Museu Nacional de História Natural e da Ciência, 96 pp

Ceríaco LMP, Marques MP, Bandeira S et al (2018a) A new earless species of Poyntonophrynus (Anura: Bufonidae) from the Serra da Neve Inselberg, Namibe Province, Angola. Zookeys 780:109-136

Ceríaco LMP, Marques MP, Bandeira S et al (2018b) Herpetological survey of Cangandala National Park, with a synoptic list of the amphibians and reptiles of Malanje Province, Central Angola. Herpetological Review 49(3):408-431

Channing A (1993) A new grass frog from Namibia. S Afr J Zool 28:142-145

Channing A (1999) Historical overview of amphibian systematics in Southern Africa. Trans Royal Soc S Afr 54(1):121-135

Channing A (2001) Amphibians of central and southern Africa. Cornell University Press, New York, 470 pp

Channing A, Baptista N (2013) Amietia angolensis and A. fuscigula (Anura: Pyxicephalidae) in southern Africa: a cold case reheated. Zootaxa 3640(4):501-520

Channing A, Griffin M (1993) An annotated checklist of the frogs of Namibia. Modoqua 18:101-116

Channing A, Vences M (1999) The advertisement call, breeding biology, description of the tadpole and taxonomic status of Bufo dombensis, a little-known dwarf toad from southern Africa. S Afr J Zool 34:74-79

Channing, A., and D. G. Broadley. 2002. A new snout-burrower from the Barotse Floodplain (Anura: Hemisotidae: Hemisus). Journal of Herpetology 36: 367-372.

Channing A, Rödel MO, Channing J (2012) Tadpoles of Africa: the biology and identification of all known tadpoles in sub-Saharan Africa. Edition Chimaira, Frankfurt, 401pp

Channing A, Hillers A, Lötters S et al (2013) Taxonomy of the super-cryptic Hyperolius nasutus group of long reed frogs of Africa (Anura: Hyperoliidae), with descriptions of six new species. Zootaxa 3620(3):301-350

Channing A, Dehling JM, Lötters S et al (2016) Species boundaries and taxonomy of the African river frogs (Amphibia: Pyxicephalidae: Amietia). Zootaxa 4155(1):1-76

Clark VR, Barker NP, Mucina L (2011) The great escarpment of southern Africa: a new frontier for biodiversity exploration. Biodivers Conserv 20(12):2543-2561

Coetzer W (2017) Occurrence records of southern African aquatic biodiversity. Version 1.10. The south African Institute for Aquatic Biodiversity. Occurrence dataset https://doi.org/10.15468/ pv7vds. Accessed via GBIF.org

Conradie W, Bills R (2017) Wannabe Ranid: notes on the morphology and natural history of the Lemaire's toad (Bufonidae: Sclerophrys lemairii). Salamandra 53(3):439-444

Conradie W, Branch WR, Measey GJ et al (2012) A new species of Hyperolius Rapp, 1842 (Anura: Hyperoliidae) from the Serra da Chela mountains, South-Western Angola. Zootaxa 3269(1): $1-17$

Conradie W, Branch WR, Tolley KA (2013) Fifty Shades of Grey: giving colour to the poorly known Angolan Ashy reed frog (Hyperoliidae: Hyperolius cinereus), with the description of a new species. Zootaxa 2636(3):201-223

Conradie W, Bills R, Branch WR (2016) The herpetofauna of the Cubango, Cuito, and lower Cuando river catchments of South-Eastern Angola. Amphibian Reptile Conserv 10(2):6-36

Crawford-Cabral JC (1966) Some new data on Angolan Muridae. Zool Afr 2:193-203 
Crawford-Cabral J, Mesquitela LM (1989) Índice toponímico de colheitas zoológicas em Angola. Instituto de Investigação Cientifica Tropical, Centro de Zoologia, Lisbon, 206

Cunningham M, Cherry MI (2004) Molecular systematics of African 20-chromosome toads (Anura: Bufonidae). Mol Phylogenet Evol 32(3):671-685

Curtis B, Roberts KS, Griffin M et al (1998) Species richness and conservation of Namibian freshwater macro-invertebrates, fish and amphibians. Biodivers Conserv 7(4):447-466

Davic RD, Welsh JHH (2004) On the ecological roles of salamanders. Annu Rev Ecol Evol Syst 35:405-434

Dehling JM, Sinsch U (2013a) Diversity of Ptychadena in Rwanda and taxonomic status of $P$. chrysogaster Laurent, 1954 (Amphibia, Anura, Ptychadenidae). Zoo Keys 356:69-102

Dehling JM, Sinsch U (2013b) Diversity of Ridged Frogs (Anura: Ptychadenidae: Ptychadena spp.) in wetlands of the upper Nile in Rwanda: morphological, bioacoustic, and molecular evidence. Zoologischer Anzeiger 253(2):143-157

Du Preez L, Carruthers V (2009) A complete guide to the frogs of Southern Africa. Struik Publishers, Cape Town, $488 \mathrm{pp}$

Du Preez L, Carruthers V (2017) Frogs of Southern Africa: a complete guide. Struik Publishers, Cape Town, $520 \mathrm{pp}$

Ernst R, Nienguesso ABT, Lautenschlaeger T et al (2014) Relicts of a forested past: southernmost distribution of the hairy frog genus Trichobatrachus Boulenger, 1900 (Anura: Arthroleptidae) in the Serra do Pingano region of Angola with comments on its taxonomic status. Zootaxa 3779(2):297-300

Ernst R, Schmitz A, Wagner P, Branquima MF et al (2015) A window to Central African forest history: distribution of the Xenopus fraseri subgroup south of the Congo Basin, including a first country record of Xenopus andrei from Angola. Salamandra 52(1):147-155

Ferreira JB (1897) Lista dos reptis e amphibios que fazem parte da última remessa de J. d'Anchieta. Jornal de Sciências Mathemáticas, Physicas e Naturaes 5(2):240-246

Ferreira JB (1900) Sobre alguns exemplares pertencentes à fauna do norte de Angola (Reptis, Batrachios, Aves e Mammiferos). Jornal de Sciências Mathemáticas, Physicas e Naturaes, Lisboa 2(6):48-54

Ferreira JB (1904) Reptis e amphibios de Angola da região ao norte do Quanza (Collecção Newton 1903). Jornal de Sciências Mathemáticas, Physicas e Naturaes, Segunda Série 7(26):111-117

Ferreira JB (1906) Algumas espécies novas ou pouco conhecidas de amphibios e reptis de Angola (Collecção Newton - 1903). Jornal de Sciências Mathemáticas, Physicas e Naturaes, Segunda Série 7(26):159-171

Frétey T, Dewynter M, Blanc CP (2011) Amphibiens d'Afrique central et d'Angola. Clé de détermination ilustrée desamphibiens du Gabo et du Mbini/Illustrated identification key of the amphibians from Gabon and Mbini. Biotope, Mèze/Muséum national d'Histoire naturelle, Paris, $232 \mathrm{pp}$

Frost DR (2018) Amphibian species of the world: an online reference. Version 6.0. Electronic database accessible at http://research.amnh.org/herpetology/amphibia/index.html. American Museum of Natural History, New York

Frost DR, Grant T, Faivovich J et al (2006) The amphibian tree of life. Bull Am Mus Nat Hist 297:1-370

Furman BL, Bewick AJ, Harrison TL et al (2015) Pan-African phylogeography of a model organism, the African clawed frog 'Xenopus laevis'. Mol Ecol 24(4):909-925

Greenbaum E, Meece J, Reed KD et al (2014) Amphibian chytrid infections in non-forested habitats of Katanga, Democratic Republic of the Congo. Herpetol Rev 45:610-614

Günther ACLG (1865 '1864') Descriptions of new species of batrachians from West Africa. Proc Zool Soc London 3:479-482

Guttman SI (1967) Transferrin and hemoglobin polymorphism, hybridization and introgression in two African toads, Bufo regularis and Bufo rangeri. Comp Biochem Physiol 23(3):871-877

Haacke WD (1999) Geographical distribution: Ptychadena mapacha Channing, 1993 - Mapacha Grass Frog. Afr Herp News 30:35 
Hall BP (1960) The faunistic importance of the scarp of Angola. Ibis 102(3):420-442

Heinicke MP, Ceríaco LM, Moore IM et al (2017) Tomopterna damarensis (Anura: Pixicephalidae) is broadly distributed in Namibia and Angola. Salamandra 53(3):461-465

Hellmich W (1957a) Die reptilienausbeute der Hamburgischen Angola Expedition. Mitteilungen aus dem Hamburgischen Zoologischen Museum und Institut 55:39-80

Hellmich W (1957b) Herpetologische Ergebnisse einer Forschungsreise in Angola. Veröffentlichungen der Zoologischen Staatssammlung München 5:1-92

Herrmann HW, Branch WR (2013) Fifty years of herpetological research in the Namib Desert and Namibia with an updated and annotated species checklist. J Arid Environ 93:94-115

Huntley BJ (1974) Outlines of wildlife conservation in Angola. J S Afr Wildl Manag Assoc 4:157-166

Huntley BJ (2019) Angola in outline: physiography, climate and patterns of biodiversity. In: Huntley BJ, Russo V, Lages F, Ferrand N (eds) Biodiversity of Angola. Science \& conservation: a modern synthesis. Springer, Cham

IUCN Red List of Threatened Species Version 2017-2. www.iucnredlist.org

IUCN Red List of Threatened Species. Version 2017-3. www.iucnredlist.org

Jongsma CF, Barej MF, Barratt CD et al (2018) Diversity and biogeography of frogs in the genus Amnirana (Anura: Ranidae) across sub-Saharan Africa. Mol Phylogenet Evol 120:274-285

Jordan K (1936) Dr Karl Jordan's expedition to South-West Africa and Angola. Narrative. Novitates Zooligicae 40:17-62, 2 maps, 5 pls

Jürgens N, Strohbach B, Lages F et al (2018) Biodiversity observation - an overview of the current state and first results of biodiversity monitoring studies. In: Revermann R, Krewenka KM, Schmiedel U et al (eds) Climate change and adaptive land management in southern Africa assessments, changes, challenges, and solutions, Biodiversity \& ecology, vol 6, pp 382-396

Köhler J, Vieites DR, Bonett RM et al (2005) New amphibians and global conservation: a boost in species discoveries in a highly endangered vertebrate group. AIBS Bull 55(8):693-696

Lamotte M, Perret JL (1961) Les formes larvaires de quelques espèces de Leptopelis: L. aubryi, L. viridis, L. anchietae, L. ocellatus et $L$. calcaratus. Bulletin de l'Institute fondamental d'Afrique noire, Sér. A 23:855-885

Laurent RF (1950) Reptiles et Batraciens de la region de Dundo (Angola du Nord-Est). Publicações culturais da Companhia de Diamantes de Angola 6:126-136

Laurent RF (1954) Reptiles et Batraciens de la région de Dundo (Angola) (Deuxième Note). Publicações culturais da Companhia de Diamantes de Angola 23:35-84

Laurent RF (1964) Reptiles et Amphibiens de l'Angola (Troisième contribution). Publicações culturais da Companhia de Diamantes de Angola 67:11-165

Marques MP, Ceríaco LMP, Bauer AM et al (2014) Geographic distribution of amphibians \& reptiles of Angola: towards an Atlas of the Angolan Herpetofauna. 12th conference of the Herpetological Association of Africa, Gobabeb, Namibia

Marques MP, Ceríaco LMP, Blackburn DC et al (2018) Diversity and distribution of the amphibians and terrestrial reptiles of Angola atlas of historical and bibliographic records (1840 -2017$)$. Proceedings of the California academy of sciences, Series 4, Volume 65, Supplement II: 1-501

Mertens R (1938a) Amphibien und Reptilien aus Angola, gesammelt von W. Schack. Senckenbergiana 20:425-443

Mertens R (1938b) Herpetologische Ergebnisse einer Reise nach Kamerun. Abhandlungen der Senckenbergischen Naturforschenden Gesellschaft, Frankfurt am Main 442:1-52

MHNG - Muséum d'histoire naturelle de la Ville de Genève (2017) Partial Amphibians Collection. Occurrence Dataset https://doi.org/10.15468/iftvxc. Accessed via GBIF.org

Minter LR, Netherlands EC, Du Preez LH (2017) Uncovering a hidden diversity: two new species of Breviceps (Anura: Brevicipitidae) from northern KwaZulu-Natal, South Africa. Zootaxa 4300:195-216

Monard A (1937) Contribuition à la Batrachologie d'Angola. Bulletin de la Société Neuchâteloise des Sciences Naturelles 62:1-59 
Nagy ZT, Kusamba C, Collet M et al (2013) Notes on the herpetofauna of Western Bas-Congo, Democratic Republic of the Congo. Herpetology Notes 6:413-419

Ohler A (1996) Systematics, morphometrics and biogeography of the genus Aubria (Ranidae, Pyxicephalinae). Alytes 13:141-166

Parker HW (1936) Dr. Karl Jordan's expedition to South West Africa and Angola: herpetological collection. Novitates Zoologicae 40:115-146

Passmore NI (1972) Intergrading between members of the "regularis group" of toads in South Africa. J Zool 167(2):143-151

Perret JL (1975) Les sous-espèces d'Hyperolius ocellatus Günther (Amphibia, Salientia). Annales de la Faculté des Sciences du Cameroun 20:23-31

Perret JL (1976) Révision des amphibiens africains et principalement des types, conservés au Musée Bocage de Lisbonne. Arquivos do Museu Bocage, Segunda Série 6(2):15-34

Perret JL (1977) Les Hylarana (Amphibiens, Ranidés) du Cameroun. Rev Suisse Zool 84:841-868

Perret JL (1996) Sur un énigmatique batracien d'Angola. Societé Neuchâteloise des Sciences Naturelles 119:95-100

Peters WCH (1877) Übersicht der Amphibien aus Chinchoxo (Westafrika), welche von der Afrikanischen Gesellschaft dem Berliner zoologischen Museum übergeben sind. Monatsberichte der Königlichen Preussische Akademie des Wissenschaften zu Berlin 1877:611-621

Peters WCH (1882) Neue Batrachier (Amblystoma Krausei, Nyctibatrachus sinensis, Bufo buchneri). Sitzungsberichte der Gesellschaft Naturforschender Freunde zu Berlin 1882:145-148

Pickersgill M (2007) Frog search. Results of expeditions to Southern and Eastern Africa from 1993-1999. Frankfurt contributions to natural history 28. Edition Chimaira, Frankfurt

Pietersen DW, Pietersen EW, Conradie W (2017) Preliminary herpetological survey of Ngonye Falls and surrounding regions in southwestern Zambia. Amphibian Reptile Conserv 11(1) [Special Section]:24-43 (e148)

Poynton JC (1964) The Amphibia of Southern Africa: a faunal study. Ann. Natal Mus 17:1-334

Poynton JC (1970) Guide to the Ptychadena (Amphibia: Ranidae) of the southern third of Africa. Ann. Natal Mus 20(2):365-375

Poynton JC, Broadley DG (1985a) Amphibia Zambesiaca 1. Scolecomorphidae, Pipidae, Microhylidae, Hemisidae, Arthroleptidae. Ann. Natal Mus 26(2):503-553

Poynton JC, Broadley DG (1985b) Amphibia Zambesiaca 2. Ranidae. Ann. Natal Mus 27(1):115-181

Poynton JC, Broadley DG (1987) Amphibia Zambesiaca 3. Rhacophoridae and Hyperoliidae. Ann. Natal Mus 28(1):161-229

Poynton JC, Broadley DG (1988) Amphibia Zambesiaca, 4. Bufonidae. Ann. Natal Mus 29(2):447-490

Poynton JC, Broadley DG (1991) Amphibia Zambesiaca 5. Zoogeography. Ann. Natal Mus 32:221-277

Poynton JC, Haacke WD (1993) On a collection of amphibians from Angola, including a new species of Bufo Laurenti. Ann Transv Mus 36(2):9-16

Poynton JC, Loader SP, Conradie W et al (2016) Designation and description of a neotype of Sclerophrys maculata (Hallowell, 1854), and reinstatement of S. pusilla (Mertens, 1937) (Amphibia: Anura: Bufonidae). Zootaxa 4098(1):73-94

Regester KJ, Lips KR, Whiles MR (2006) Energy flow and subsidies associated with the complex life cycle of ambystomatid salamanders in ponds and adjacent forest in southern Illinois. Oecologia 147(2):303-314

Rochebrune AT (1885) Vertebratorum novorum vel minus cognitorum orae Africae occidentalis incolarum. Diagnoses (1). Bulletin de la Société Philomathique de Paris 7(9):86-99

Royal Belgian Institute of Natural Sciences (2017). RBINS DaRWIN. Occurrence Dataset https:// doi.org/10.15468/qxy4mc. Accessed via GBIF.org

Royal Museum for Central Africa, Belgium (2017). RMCA-HERP. Occurrence Dataset https://doi. org/10.15468/0inmlf. Accessed via GBIF.org 
Ruas C (1996) Contribuição para o conhecimento da fauna de batráquios de Angola. Garcia de Orta, Série de Zoologia 21(1):19-41

Ruas C (2002) Batráquios de Angola em colecção no Centro de Zoologia. Garcia de Orta, Série de Zoologia 24(1-2):139-154

SASSCAL ObservationNet (2017) http://www.sasscalobservationnet.org/ consulted on March 6th 2018

Scheinberg L, Fong J (2017) CAS herpetology (HERP). Version 33.10. California Academy of Sciences. Occurrence dataset https://doi.org/10.15468/bvoyqy. Accessed via GBIF.org

Schick S, Kielgast J, Rödder D et al (2010) New species of reed frog from the Congo basin with discussion of paraphyly in Cinnamon-belly reed frogs. Zootaxa 2501:23-36

Schiøtz A (1999) Treefrogs of Africa. Editions Chimaira, Frankfurt am Main, 350 pp

Schiøtz A, Van Daele P (2003) Notes on the treefrogs (Hyperoliidae) of North-Western Province, Zambia. Alytes 20:137-149

Schmidt KP (1936) The amphibians of the Pulitzer-Angola expedition. Ann Carnegie Mus 25:127-133

Steindachner F (1867) Reise der österreichischen Fregatte Novara um die Erde in den Jahren 1857, 1858, 1859 unter den Bafehlen des Commodore B. von Wüllerstorf-Urbair. Zologischer Theil. 1. Amphibien. Wien: K. K. Hof- und Staatsdruckerei. 70 p + 5pls

Tandy M, Keith R (1972) Bufo of Africa. In: Blair WF (ed) Evolution in the Genus Bufo. University of Texas Press, Austin/London, pp 119-170

Turner AA, Channing A (2017) Three new species of Arthroleptella Hewitt, 1926 (Anura: Pyxicephalidae) from the Cape Fold Mountains, South Africa. Afr J Herpetol 66:53-78

Uyeda JC, Drewes RC, Zimkus BM (2007) The California Academy of Sciences Gulf of Guinea expeditions (2001, 2006) VI. Proc Calif Acad Sci 58(13-22):367

Van Dijk DE (1966) Systematic and field keys to the families, genera and described species of southern African anuran tadpoles. Ann Natal Mus 18:231-286

Van Dijk DE (1971) A further contribution to the systematics of Southern African anuran tadpoles-the genus Bufo. Ann Natal Mus 21:71-76

Waddle JH (2006) Use of amphibians as ecosystem indicator species. PhD Thesis. University of Florida, Gainesville

Whiles MR, Lips KR, Pringle CM et al (2006) The effects of amphibian population declines on the structure and function of Neotropical stream ecosystems. Front Ecol Environ 4(1):27-34

Zimkus BM, Rödel MO, Hillers A (2010) Complex patterns of continental speciation: molecular phylogenetics and biogeography of sub-Saharan puddle frogs (Phrynobatrachus). Mol Phylogenet Evol 55(3):883-900

Zimkus BM, Lawson LP, Barej MF et al (2017) Leapfrogging into new territory: how Mascarene ridged frogs diversified across Africa and Madagascar to maintain their ecological niche. Mol Phylogenet Evol 106:254-269

Open Access This chapter is licensed under the terms of the Creative Commons Attribution 4.0 International License (http://creativecommons.org/licenses/by/4.0/), which permits use, sharing, adaptation, distribution and reproduction in any medium or format, as long as you give appropriate credit to the original author(s) and the source, provide a link to the Creative Commons licence and indicate if changes were made.

The images or other third party material in this chapter are included in the chapter's Creative Commons licence, unless indicated otherwise in a credit line to the material. If material is not included in the chapter's Creative Commons licence and your intended use is not permitted by statutory regulation or exceeds the permitted use, you will need to obtain permission directly from the copyright holder.

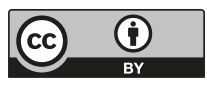

